\title{
Race, Class, and Access to Civil Justice
}

\author{
Sara Sternberg Greene $e^{*}$
}

\begin{abstract}
Existing research indicates that members of poor and minority groups are less likely than their higher income counterparts to seek help when they experience a civil legal problem. Indeed, roughly three-quarters of the poor do not seek legal help when they experience such problems. Inaction is even more pronounced among poor blacks. This Article uses original empirical data to provide novel explanations for these puzzling and troubling statistics. This study shows, for the first time, a connection between negative past experiences with the criminal justice system and decisions to seek help for civil justice problems. For those familiar with the law, civil and criminal law are separate categories across which experiences do not generalize, any more than a negative experience of subways would lead one to avoid driving. For most respondents, though, the criminal and civil justice systems are one and the same. Injustices they perceive in the criminal system translate into the belief that the legal system as a whole is unjust and should be avoided. Second, this Article shows that past negative experiences with a broad array of public institutions perceived as legal in nature caused respondents to feel lost and ashamed, leading them to avoid interaction with all legal institutions. Third, my data and interviews suggest that respondents helped make sense of these troubling experiences by more generally portraying themselves as self-sufficient citizens who solve their own problems. Seeking help from the legal system might mun counter to this selfportrayal. Finally, this Article provides a novel analysis of racial differences in how much citizens use the civil legal system and argues that disparities in trust levels help to explain these differences. This Article concludes by
\end{abstract}

* Associate Professor, Duke University School of Law. For invaluable comments and suggestions, I thank Jason Beckfield, Jaime Boyle, Rachel Brewster, Guy Charles, Kathy Edin, Daniel Greene, Maggie Lemos, Ralf Michaels, Orlando Patterson, Barak Richman, Neil Siegel, Van Tran, Neil Vidmar, and Chris Winship, as well as all of the participants of the Duke Law School January 2015 Faculty Scholarship Retreat. I also thank Alex Galbraith, Vince Geis, and Allison Schmidt, members of the Iowa Law Review, for excellent editorial work. The American Bar Association generously funded data collection and analysis. Additionally, the National Science Foundation provided support to the author for data analysis and writing. Special thanks to the residents of Cambridge, Massachusetts who agreed to be interviewed for this project and without whom this Article could never have been written. All errors are of course my own. 
discussing potential policy implications of the findings and identifies key areas for further research.

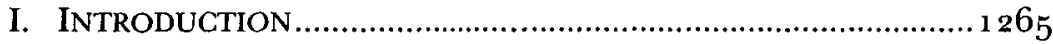

II. EXISTING APPROACHES TO ACCESS-TO-CIVIL-JUSTICE

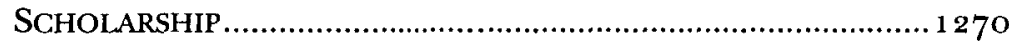

A. EXISTING RESEARCH ON ACCESS TO JUSTICE .......................... $127 \mathrm{l}$

B. EXISTING RESEARCH ON RACE AND TRUST........................... 1275

III. DATA AND METHODOLOGY................................................. 1281

A. QUALITATIVE METHODS................................................ 1281

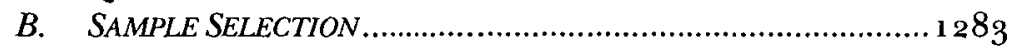

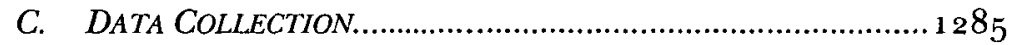

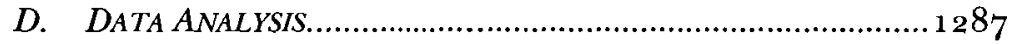

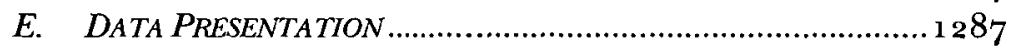

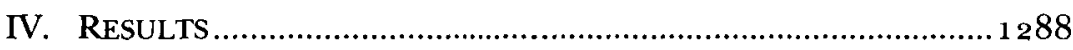

A. SHARED EXPLANATIONS FOR INACTION............................... 1288

1. "To Me It's All Law and Courts and Bad": Criminal and Civil Justice Confusion ............................................ 1289

2. "More Money, More Justice" ....................................1290

3. Past Experiences with Courts and Other

Institutions

4. "I've Made It on My Own. I Don't Need No Lawyers or

Courts": Self-Sufficiency Narratives............................. 1298

B. RACIAL DIFFERENCES IN CIVIL JUSTICE PERCEPTIONS AND

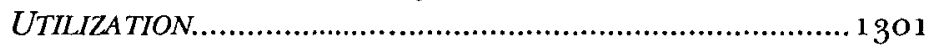

1. Race, Trust, and Use of Civil Courts........................1301

2. Racism .............................................................. 1304

3. Race, Corruption, and Use of Courts ....................... 1307

4. Civil Justice Utilization Differences: Black and White

Respondents

V. AGENDA FOR FURTHER RESEARCH AND POLICY

CONSIDERATIONS...............................................................1313

A. AGENDA FOR FURTHER RESEARCH ......................................1313

B. POLICY CONSIDERATIONS................................................ 1314

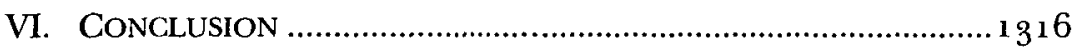

APPENDIX: CIVIL JUSTICE SURVEY ....................................... 1320 


\section{INTRODUCIION}

Tonya, a mother of two young children and a respondent in this study, was evicted by her landlord because she asked him one too many times to fix unsafe conditions in her apartment, including exposed electrical wires. Tonya, worried about the safety of her children, was persistent. After her third phone call, Tonya's landlord informed her that he no longer wanted to rent to her because she was a "pain" and that she had one-and-a-half weeks to move out (until the end of the month). Tonya's lease was valid for five more months, but her landlord refused to change his mind. Tonya pleaded and then argued with her landlord, even threatening legal action, but she never sought the advice of a lawyer or seriously considered bringing her landlord to court. Tonya's landlord refused to return her security deposit, and she could not afford to pay another one, so she moved into cramped quarters with her mother until she got off the waitlist for public housing several years later. This move was the catalyst for a series of negative events for Tonya-an over twohour commute to work on public transportation, eventually being fired for one too many tardies (due to unreliable public transportation), and over a year of barely keeping afloat while looking for a new job. ${ }^{1}$

Tonya's decision not to seek legal help is common. A national study by the American Bar Association found that among low income individuals like Tonya, $47 \%$ were experiencing one or more civil legal needs ${ }^{2}$ at the time of the survey. ${ }^{3}$ Of those $47 \%$, only about one-quarter sought legal advice. 4 Nearly three-quarters shunned the justice system entirely, not even taking the first step of picking up the phone to find out what kind of legal help might be available. 5

In a society that many consider too litigious, ${ }^{6}$ these percentages are staggering. Existing research shows that low income individuals are

1. See infra Parts IV.A.3 \& VI for further details about Tonya's experience and a discussion of what may have happened had Tonya sought the help of a lawyer.

2. The American Bar Association administered a comprehensive survey asking about a wide range of civil legal needs. I used the same to set the scope of civil legal needs for this Article with the exception of a few areas that I thought were unlikely to be relevant to my sample, such as problems with farming, problems with condo boards, and problems related to being Native American. For a complete list of these civil problems, see infra Appendix.

3. Consortium on legal Servs. \& the Pub., Am. Bar. Ass'n, Legal Needs and Civil JUSTICE: A SURVEY OF AMERICANS: MAJOR FINDINGS FROM THE COMPREHENSIVE LEGAL NEEDS STUDY (1994), http://www.americanbar.org/content/dam/aba/migrated/legalservices/downloads/sclaid/ legalneedstudy.authcheckdam.pdf.

4. Id. The total percentages add up to more than $100 \%$ because the survey allowed individuals to select more than one action.

5. Id.

6. See Richard E. Miller \& Austin Sarat, Grievances, Claims, and Disputes: Assessing the Advers6.y Culture, 15 LAW \& SOC'Y REV. 525, 532 (1980-1981) (noting that many believe American society is overly litigious). Other examples include cases like the infamous "McDonald's Coffee Case," in which a woman spilled McDonald's coffee on herself, suffered third-degree 
significantly more likely to report experiencing civil legal problems than their higher income counterparts, 7 but that they are less likely to resolve these problems through the legal system than are people of higher socioeconomic levels. ${ }^{8}$ Additionally, a recent survey found that non-whites are significantly more likely than whites to report experiencing civil legal problems. ${ }^{9}$

What is unclear from existing research, however, is why people like Tonya are unlikely to seek legal help, even when they are aware free help is available. This Article seeks to explore both why such a large proportion of poor people do not seek civil legal help and how these reasons may differ based on race. This Article utilizes original, empirical data from a large-scale in-depth interview study of 97 respondents to explore the underlying cultural and cognitive mechanisms for this resistance. ${ }^{10}$ The findings uncover a new perspective on access to justice that is vital to consider when designing accessto-justice policy.

First, negative past experiences with-and perceptions of-the criminal justice system significantly contribute to resistance to seeking out help from

burns, and was awarded millions of dollars in damages. Liebeck v. McDonald's Rests., P.T.S., Inc., No. CV-93-02419, 1995 WL 36o3o9 (D.N.M. Aug. 18, 1994), vacated per stipulation, 1994 WL 16777704 (D.N.M. Nov. 28,1994 ). ABC News called the case "[ $\mathrm{t}]$ he poster child of excessive lawsuits" and much controversy erupted. Lauren Pearle, 'I'm Being Sued for WHAT?, 'ABC NEWs (May 2, 2007), http://abcnews.go.com/TheLaw/story?id=3121086\&page $=1$. This case and others like it sparked calls for reform, with the argument that Americans are overly litigious and will sue for anything just to make a quick buck. Id.

7. A recent survey that randomly sampled residents of a midwestern city found that almost $80 \%$ of low income respondents had experienced a civil legal problem, as compared to just over $60 \%$ of middle income respondents and a similar number of high income respondents. The authors tested the difference using statistical methods and found a significant difference $(p<0.001)$. REBECCA L. SANDEFUR, AM. BAR FOUND., ACCESSING JUSTICE IN THE CONTEMPORARY USA: FINDINGS FROM THE COMMUNITY NEEDS AND SERVICES STUDY 9 fig.3 (2014), http://www.americanbarfoundation.org/ uploads/cms/documents/sandefur_accessing_justice_in_the_contemporary_usa._aug._2014.pdf.

8. See, e.g., Miller \& Sarat, supra note 6, at 551-54; Rebecca L. Sandefur, Access to Civil Justice and Race, Class, and Gender Inequality, 34 ANN. REV. SoC. 339, 346-49 (2008). These disparities in civil justice experiences and utilization are important because they "can be ... engine[s] in reproducing inequality." Sandefur, supra, at 34o, 346-49. How people respond to civil justice issues (through legal action or inaction) is "associated with whether problems resolve or persist" and whether the problems create new ones, spiraling into "cascades of trouble." Id. See generally hazel Genn, Paths to Justice: What People do and Think about Going to law (1999). Additionally, civil justice problems have documented negative impacts on people's lives, and the magnitude of the negative impacts have been found to be more severe for low income households. Sandefur, supra note 7 , at 10 . People in low income households are most likely to report negative consequences for civil legal problems, and white people in high income households are the least likely to report negative consequences. Id. at 9; Sandefur, supra, at 347. Thus, socioeconomic and racial differences in how people respond to civil legal problems "can mean that the same initial event ... creates very different consequences for those in different" social classes and of different races. Id.

9. SANDEFUR, supra note 7 , at 8,9 fig.3.

10. Several important studies in legal scholarship have been conducted using qualitative methods, a standard research technique in the social sciences. For further discussion of the value of qualitative research, see infra Part III.A. 
the civil justice system. The data show that the majority of respondents believed that seeking help from legal institutions would likely be futile, and based this conclusion largely on their perceptions of fairness in the criminalrather than civil-justice system. For most respondents, the criminal and civil justice systems are one and the same, and injustices they perceive in the criminal justice system translate into their belief that the justice system as a whole is unjust. Their most salient complaint was that the justice system is one in which justice is "bought." " They believe that if one does not have money to pay for an expensive lawyer, seeking out help from a free lawyer will be unlikely to resolve the problem. ${ }^{22}$

Second, and relatedly, many respondents indicated that their past experiences with public institutions-including the criminal justice system and public benefit hearings they perceived to be criminal in nature-were negative. They felt "disrespected," "pathetic," "shameful," "lost," and unsure how to navigate the system. ${ }^{13}$ These past experiences directly affected their desire to get involved in any kind of formal legal proceeding. ${ }^{4}$ Taking no action to resolve their problem was more desirable than taking action that would result in similar negative feelings, even if inaction meant more financial and emotional stress. Indeed, seeking out lawyers and going to court for civil justice issues would mean bringing themselves back into the claws of an institution that they do not understand and in which they feel lost, risking the very same feelings of shame and failure they wish to avoid.

Finally, in part as a way to make sense of their past perceptions of, and experiences with, the criminal justice system and other public institutions, many respondents developed personal narratives as self-sufficient citizens who take care of their own problems and stay "out of trouble." 15 Seeking help from the legal system was counter to this identity. ${ }^{16}$

11. See infra Part IV.A.

12. Many of the concerns of respondents are certainly rational. For example, the Department of Justice's recent inquiry in the police and courts of Ferguson, Missouri, found that Ferguson's municipal courts function primarily with the goal of "maximizing revenue," rather than the "goal of administering justice or protecting the rights of the accused." CIVL RIGHTS DIV., U.S. DEP'T OFJUSTICE, INVESTIGATION OF THE FERGUSON POLICE DEPARTMENT 42 (2015), http://www.justice.gov/sites/default/files/ $\mathrm{opa} /$ press-releases/attachments/2015/o3/04/ferguson_police_department_report.pdf. The report goes on to state that the department's investigation "uncovered substantial evidence that the court's procedures are constitutionally deficient and function to impede a person's ability to challenge or resolve a municipal charge." Id. Finally, the report notes that these practices "undermine[] police legitimacy and community trust." Id.

13. See infra Part IV.A.3.

14. See infra Part IV.A.3.

15. See infra Part IV.A.4.

16. There were other explanations for inaction that were not prevalent enough to warrant detailed explanation but were indeed repeated by more than one respondent. Examples of such explanations include concern about retaliation, inability to take time off from work to meet with a lawyer, and not knowing where to seek help, among others. 
This Article explores not only why poor people are unlikely to seek help for civil legal problems, but also whether there are racial differences in the mechanisms behind this decision. In recent years, researchers have devoted considerable energy to studying the relationship between race and the criminal justice system, ${ }^{17}$ with important research emerging about racial sentencing disparities, ${ }^{8}$ race and mass imprisonment, ${ }^{19}$ and racial differences in perceptions of criminal injustice.$^{20}$ By contrast, almost no attention has been paid to racial differences in civil justice utilization or outcomes."1 Indeed, existing research about racial differences in civil justice utilization is even less developed than research about socioeconomic differences; it is essentially nonexistent. ${ }^{22}$

The findings of this study are a first attempt at piercing this important and underdeveloped area of inquiry. The black respondents in this study were less likely than white respondents to have sought, or considered seeking, legal help for their civil legal problems. ${ }^{23}$ These racial differences were primarily explained by racial differences in trust in institutions. Consistent with past research about race and trust, ${ }^{24}$ black respondents were more likely to distrust legal institutions than were white respondents. The majority of black respondents, when asked whether they trusted courts, answered the question in a generalized way, indicating they trust almost no one but themselves. ${ }^{25}$ White respondents were more likely to offer nuanced evaluations of their level of trust in legal institutions, often basing their conclusions on their own past experiences with institutions, or those of friends or family members. Blacks' distrust of the legal system led them to be particularly resistant to seeking out help, and this distrust was a strong contributor to the self-sufficient narratives the respondents constructed. ${ }^{26}$

The results from this study are particularly important because, after years of relative inattention to access-to-civil-justice matters, there is a renewed

17. See, e.g., Bruce WESTERn, Punishment ANd IneQUality in AMERICA (2006); John Hagan \& Celesta Albonetti, Race, Class, and the Perception of Criminal Injustice in America, 88 AM. J. SoC. 329 (1982); Scot Wortley et al., Just Des(s)erts? The Racial Polarization of Perceptions of Criminal Injustice, 31 LAW \& SOC'Y REV. 637 (1997).

18. See, e.g., RANDALL KENNEDY, RACE, CRIME, AND THE LAW (1997).

19. See, e.g., WESTERN, supra note 17.

20. See, e.g., Hagan \& Albonetti, supra note 17; Wortley et al., supra note 17.

21. Sandefur, supra note 8 , at $35^{\circ}$.

22. See id. (" $[\mathrm{N}]$ o work from the contemporary national surveys has yet focused on measuring and explaining race differences in the incidence of problems, in disputing behavior, in how problems are handled .... Nor has work from these surveys yet explored race differences within socioeconomic groups .... . No major qualitative study has focused expressly on race and disputing, justiciable problems, or contact with civil courts or staff.").

23. See infra Part IV.B.4.

24. See infra Part II.B.

25. See infra Part IV.B.1.

26. See infra Part IV.B. 
energy and movement among policymakers to address access-to-justice disparities. For instance, in 2010, the United States Department of Justice ("DOJ") created the Access to Justice Initiative. ${ }^{27}$ Subsequently, in September 2014, the incoming President of the American Bar Association made "clos[ing] the widening gap in legal services delivery to [the] poor" his top priority, ${ }^{28}$ and the National Science Foundation released an announcement noting its interest in supporting "research concerning the use and functioning of the civil justice system." 29

Additionally, in the wake of the recent deaths of black citizens during interactions with police officers and the waves of protests that followed,,$^{\circ}$ new initiatives focused on criminal justice and government/community relations have developed. For example, in September 2014, then-U.S. Attorney General Eric Holder announced the launch of the DOJ's National Initiative for Building Community Trust and Justice. This initiative is tasked with "enhanc[ing] community trust and help[ing] repair and strengthen the relationship between law enforcement and the communities they serve." 31

While there is a renewed interest is designing policy to increase access to civil justice for the poor and racial minorities, the lack of research available to inform policy reforms is striking. Much of the access-to-justice scholarship that does exist focuses on structural and systemic resource constraints to access such as long waitlists for free legal service lawyers, unrealistic income ceilings for free legal services, and reductions in pro bono requirements in big law firms..$^{2}$ There is no doubt that concern about a lack of available lawyers for

27. Access to Justice: About the Office, U.S. DEP'T JUST., http://www.justice.gov/atj/about-office (last visited Mar. 8, 2016). The purpose of the initiative is to work with "system stakeholders to increase access to counsel and legal assistance and to improve the justice delivery systems that serve people who are unable to afford lawyers." Id. When Attorney General Eric Holder discussed the program he said: "Today, the current deficiencies in our indigent defense system and the gaps in legal services for the poor and middle class constitute not just a problem, but a crisis. And this crisis appears as difficult and intransigent as any now before us." Id. (quoting Eric Holder, Attorney Gen., Remarks at the Shriver Center Awards Dinner (Oct. 14, 2010)).

28. James Podgers, New ABA President William Hubbard Wants to Close Legal Services Delivery Gap for Poor, A.B.A. J. (Sept. 1, $2014,7: 40$ AM), http://www.abajournal.com/magazine/article/ new_aba_president_william_hubbard_wants_to_closing_the_gap_in_legal_service.

29. Myron Gutmann, Dear Colleague Letter-Stimulating Research Related to the Use and Functioning of the Civil Justice System, NAT'L SCI. FouND. (Mar. 15, 2013 ), http://www.nsf.gov/pubs/2013/nsf $13076 /$ nsf $13076 . j s p$.

3o. For a discussion of these police encounters and the resulting protests and social movements, see Jonathan Capehart, From Trayvon Martin to 'Black Lives Matter,' WASH. POST (Feb. 27, 2015), https://www.washingtonpost.com/blogs/post-partisan/wp/2015/o2/27/from-trayvonmartin-to-black-lives-matter.

31. See Bureau of Justice Assistance, U.S. Dep't of Justice, Resource Guide for Enhancing Community Relationships and PRotecting PRIVACy and Constitutional Rights 4 (2014), http://www.bja.gov/publications/CommRelGuide.pdf.

32. Deborah Rhode was groundbreaking in bringing attention to these important systemic problems. See, e.g., DEBORAH L. RHODE, ACCESS TO JUSTICE 185-93 (2004); Colloquy, Deborah $L$. Rhode's Access to Justice, 73 FORDHAM L. REV. 841 (2004). Rebecca Sandefur's work is an 
those who seek help is warranted. Indeed, "more than half of those who seek help [from federally funded civil legal aid programs] are turned away." 33 This Article, however, focuses on a different issue that is only beginning to receive attention: the decision of families like Tonya's and the nearly three-quarters of poor households that do not even take the first step towards seeking legal help when they experience a civil justice problem.34 It shows that access problems are broader than just structural and systemic restraints-there are also cultural and cognitive barriers to access that need to be considered. These cultural and cognitive barriers are certainly related to (and perhaps even stem from) the existing structural restraints of the system, but they have taken on a life of their own and deserve attention and study.

The remainder of this Article is organized as follows. Part II details existing approaches to access-to-justice scholarship, noting how this study can help address certain gaps in current understanding about access to civil justice. Part III describes the methodology and data for this study. Next, Part IV proceeds by describing the socioeconomic and race findings of the study. Notably, this Article makes previously undetected connections between experiences with the criminal justice system and utilization of the civil justice system that are vital to designing effective policy. Because these civil and criminal justice connections have not yet been documented, current policy initiatives do not address or capitalize on them. Therefore, in Part V, this Article examines the potential policy implications of this work and proposes an agenda for further research, and Part VI concludes.

\section{EXISTING APPROACHES TO ACCESS-TO-CIVIL-JUSTICE SCHOLARSHIP}

Despite a great deal of interest among socio-legal scholars in studying race and class disparities in the criminal justice system, 35 there has been relatively little work examining similar disparities in the civil justice system. This dearth of work is surprising because civil legal issues touch on almost all facets of social life; such issues "are empirically frequent and can have significant and far-reaching consequences." 36 The most commonly reported

important exception to this focus on systemic barriers to access. For example, she conducted a small focus group study (29 people) of low and low-moderate income residents in a midwestern American city that sought to better explain inaction. She asked participants in her focus groups about how they dealt with financial and housing problems with a focus on inaction. See Rebecca L. Sandefur, The Importance of Doing Nothing: Everyday Problems and Responses of Inaction, in Transforming Lives: LaW and Social Process 11 2, 11 7-19 (Pascoe Pleasence et al. eds., 2007).

33. Access to Justice: About the Office, supra note 27.

34. See supra text accompanying notes 4-5.

35. See generally WESTERN, supra note 17.

36. See Sandefur, supra note 8, at $34^{\circ}$ (describing how the American civil justice system "can be an important engine in reproducing inequality"). 
civil legal issues involve housing and finances, 37 issues that are routinely studied by scholars of inequality in non-legal contexts. $3^{8}$

Indeed, access-to-justice issues should be at the forefront of socio-legal studies because existing research shows that civil justice experiences can be significant in perpetuating inequality and can have a profound impact not only on those who experience them, but also on their families, neighborhoods, and communities.39 Additionally, as Rebecca Sandefur notes, "the civil justice system is... one of the major social institutions in contemporary [American] societ[y]." $4^{\circ}$ Investigations into access-to-justice issues for different groups can provide a lens into how our civil legal institutions may aid in the perpetuation of inequality and how different groups are integrated into-and excluded from-public institutions. 4 ' There has been some work, however, that touches on relevant civil justice issues and this Article builds off of this existing work. This Part details several different approaches to studying civil justice and discusses the gaps in the literature left by the existing literature that this Article seeks to fill. This Part also discusses existing research on race and trust that provides an important backdrop to the race findings in this Article.

\section{A. EXISTING RESEARCH ON ACCESS TO JUSTICE}

There have been several important theoretical and empirical contributions to access-to-justice research that paved the way for this study. One approach, the legal consciousness approach, seeks to understand the "subtle ways in which law affects the everyday lives of individuals to articulate the various understandings of law/legality that people have and use to construct their understanding of their world." $4^{2}$ The idea of the legal consciousness approach is to study "not only ... how people think about the law ... but also the ways in which largely unconscious ideas about the law can affect decisions they make." 43

37. See id. (stating that problems like paying property taxes and the inability to pay bills are top sources of reported inequality).

$3^{8}$. See id. at $34^{\circ}-45$ (discussing the historical emergence of social scientific studies regarding access-to-justice systems); see also, e.g., DOUGlas S. MASSEY \& NANCY A. DENTON, AMERICAN APARTHEID: SEgREGATION AND THE MAKING OF THE UNDERCLASS (1993); VIVIANA A. ZELIZER, ECONOMIC LIVES: HOW CULTURE SHAPES THE ECONOMY (2011).

39. SANDEFUR, supra note 7 , at 9-10 (presenting findings regarding civil justice's impact on social inequality).

4o. Id.

41. Id.

42. See generally Laura Beth Nielsen, Situating Legal Consciousness: Experiences and Attitudes of Ordinary Citizens About Law and Street Harassment, 34 LAW \& SOC'Y REV. 1055 (2000).

43. Id. 
Ewick and Silbey, important pioneers in this approach, found that ordinary citizens use three different schemas to understand the law.44 Most relevant to this study is the adversarial schema-a schema invoked by people who have an adversarial relationship with the law and view it as something to be resisted.45 While the authors state that marginalized groups tend to invoke the adversarial schema more often than non-marginalized groups, they did not confirm this empirically or claim to have analyzed their data with this in mind. Thus, while their work is helpful in understanding how people construct the law, we know little about how this may vary by socioeconomic status or race and why different groups may invoke different schemas. $4^{6}$

Gap studies, as they have been termed, are also important precursors for this study. Gap studies attempt to understand if and why there are differences between formal law (constitutional or statutory) and law in action (what people's actual experiences are with the area of law being studied).47 Gap studies have found there are situations in which groups develop their own norms that are outside of, or contrary to, the law on the books. It is these norms, rather than formal law, that rule. $4^{8}$ Gap studies were important to the theoretical design of this study because one hypothesis that I considered was that respondents were not bringing civil justice issues to the formal legal system because they were invoking established social norms outside of the formal law in order to resolve the issues. This hypothesis was proven to be false among the respondents in this study but was nonetheless important to explore in the interviews.

The "top-down" approach to the study of access to justice starts with legal institutions and focuses on aspects of these institutions that affect whether

44. Patricia EWICK \& Susan S. SILbey, The Common Place of LAW: STORIES From EVERyday LIFE (1998).

45. See id. at $233-41$.

46. See id. at 230-50. Since Ewick and Sibley published their study, others have noted their lack of attention to marginalized populations. There have since been studies of very specific groups of marginalized people. See, e.g., Kay Levine \& Virginia Mellema, Strategizing the Street: How Law Matters in the Lives of Women in the Street-Level Drug Economy, 26 LAW \& SOC. INQUIRY 169 (2001) (studying women who are involved in selling drugs on the street and finding that the law is neither a structural constraint nor a tool for empowerment in the lives of these women but, instead, that the law comes second to other considerations that are more salient to their daily survival); Nielsen, supra note 42 (studying racial and gender differences in beliefs about offensive speech regulation and finding that there are differences depending on race and gender).

47. Sandefur, supra note 8 , at $34^{\circ-4}$.

48. See, e.g., Robert C. Ellickson, Order Without Law: How Neichbors Settle DISPUTES (1991) (studying ranchers and farmers in rural California and finding that they settle disputes completely ignorant of their legal rights because most people in the area find the costs of learning about the law and submitting to formal resolution procedures to be so high that it is easier to fall back on norms); Stewart Macaulay, Non-Contractual Relations in Business: A Preliminary Study, 28 AM. SoC. REv. 55 (1963) (studying businessmen in contractual relations and finding that they frequently settle their disputes without regard to the original contract in place or reference to potential legal sanctions because they believe that they can settle disputes better than their lawyers). 
people seek remedies through them. Much of the top-down literature focuses on lawyers-their availability, affordability, and role as gatekeepers. 49 In addition to Rhode's work on systemic barriers to access to civil justice for the poor,$^{\circ}$ Macaulay's classic study of consumer protection lawyers emphasizes the extent to which lawyers serve as gatekeepers, keeping different groups and types of claims out of the formal legal system..$^{11}$ Macaulay found that lawyers view being a gatekeeper as part of their role, keeping out those who, in their opinion, may unnecessarily burden the system. Like Rhode, he found that economics of practice are a significant factor in how lawyers behave and that low income and poor clients are often penalized..$^{2}$ In designing the interview questions for this study, I included questions about legal institutions to better understand, from the perspective of potential low income clients, the specific role these institutions may be playing in creating barriers to access. What I found, however, was that for the majority of the respondents in this study, the structural/systemic barriers that Rhode, Macauley, and others have pinpointed did not apply because the respondents did not attempt to gain access or pursue legal help for their problems. Knowledge of these barriers may have influenced their decisions not to seek help, but the barriers in and of themselves did not prevent access.

Finally, and most relevant to this study's approach, is the "bottom-up" approach to studying legal problems. This strand of research strives to explain "the process by which a legal system acquires its cases," 53 or how events perceived as injurious become formal disputes engaged by the formal legal system.54 Bottom-up scholars use, as a starting point, events that involve legal issues, but may or may not reach the point of a legal action.55 Such research may begin by studying grievances-events or circumstances that people perceive as personally injurious and the fault of another party. $5^{6}$ Several studies track how grievances transform into claims for remedy, and if these claims are denied, why and how the disputes are or are not taken to formal legal institutions for resolution.57

49. See, e.g., RHODE, supra note 32; Stewart Macaulay, Lawyers and Consumer Protection Laws, 14 LAW \& SOC'Y REV. 115 (1979).

5o. RHODE, supra note 32 . Rhode also notes that in cases where the poor are provided with court-appointed lawyers, the incentive system is perverse because such lawyers do not need to focus on client satisfaction in order to stay in business. Id. at 11-13.

$5^{\text {l. }}$ Macaulay, supra note 49 , at $122-25$.

52. See id.

53. Donald J. Black, The Mobilization of Law, 2 J. LeGAL STUD. $125,13^{0-44}$ (1973).

54. Sandefur, supra note 32 , at 115 .

55. Black, supra note 53 , at 126.

56. See generally William L.F. Felstiner et al., The Emergence and Transformation of Disputes: Naming, Blaming, Claiming. .., i 5 LAW \& SOC'Y REV. 631 (1980-1981).

57. See, e.g., CAROL J. GREenHOUSE ET AL., LAW AND COMMUNITY IN THREE AMERICAN TOWNS (1994); Felstiner et al., supra note 5 ; Marc Galanter, Reading the Landscape of Disputes: What We Know and Don't Know (and Think We Know) About Our Allegedly Contentious and Litigious Society, $3^{1}$ 
One of the most well-known frameworks that employs this research method is the "naming, blaming, and claiming" study. The study sought to explain how injurious experiences were identified (naming), causally attributed to second parties as grievances (blaming), and, sometimes, ultimately settled in a court of law (claiming) $.5^{8}$ One of the key findings of this study was that high income households were more likely than low income households to seek a legal remedy for events considered to be a grievance.59 Further, the study found that these socioeconomic differences in civil justice utilization are likely explained by unequal distribution of resources that facilitate the law's use, such as money and knowledge. ${ }^{\text {io }}$ This includes not just money to hire a lawyer, but also additional expenses, such as the money to travel to a legal aid office or the knowledge that solutions exist. ${ }^{61}$

Since the naming, blaming, and claiming study, there have been a few other published studies that have furthered knowledge about how and why different groups may bring claims to the formal legal system. ${ }^{62}$ Most of these studies focused on either working-class or upper-class neighborhoods. ${ }^{63}$

More recently, Rebecca Sandefur has considered the question of why most poor people do not seek help for their civil legal problems. Sandefur has noted that existing sociological research about inequality and social class suggests that "people whose social position is near the bottom of an unequal structure will be less likely to take actions that might protect or further their own interests," and that these actions are not limited to legal actions, but can also include "seeking information or advice, pressing claims with others seen as causing a problem, or attempting to mobilise [sic] third parties in the furtherance of their goals." 64

UCLA L. REV. 4 ( $19^{83}$ ); Miller \& Sarat, supra note 6; Calvin Morrill et al., Legal Mobilization in Schools: The Paradox of Rights and Race Among Youth, 44 LAW \& SOC'Y REV. 651 (2010).

58 . Felstiner et al., supra note $5^{6}$, at $633-37$; Miller \& Sarat, supra note 6, at 536-42.

59. Miller \& Sarat, supra note 6 , at 552 tbl. 4 .

6o. Felstiner et al., supra note 5 , at $649-50$; Miller \& Sarat, supra note 6 , at $55^{1-52}$.

61. Sandefur, supra note 32 , at 116 .

62. Greenhouse studied three small American towns and found that the towns were built on a foundation of individualism that promoted not blaming others for one's problems. Thus, when outsiders sued small businesses, for example, they were ostracized. However, there was contradiction because when the towns' insiders wished to take their problems to court to defend their contracts or leases, they used the law successfully and felt that it was justified. See generally GREENHOUSE ET AL., supra note 57. Sally Engle Merry studied working class Americans in a small New England town in the 1980 and found that they had a strong belief in the law. It was only after they invoked the law and were diverted, discouraged, or delayed by law clerks that they began to lose faith in the law. Merry argued that they initially invoked the formal legal system to settle disputes because they had a sense of entitlement to the law that was rooted in the history of the working class in New England. See generally SAlly ENGLE MERRY, GETTING JuSTICE AND GETTING EVEN: LegAL CONSCIOUSNESS AMONG WORKING-CLASS AMERICANS (1990). These studies are dated and focus on non-poor Americans and their relationships to the justice system.

63. See, e.g., GREENHOUSE ET AL., supra note 57; MERRY, supra note 62.

64. Sandefur, supra note 32 , at 117. 
Sandefur conducted a small focus group study-29 people in one midwestern city-to examine why low income people are resistant to seeking out help specific to money and housing problems..$_{55}^{6_{5}}$ Sandefur's work provides a key insight that past experiences can play a role in low income individuals' decision-making surrounding legal needs.66 However, Sandefur's findings suggest that it is primarily past experiences with the specific parties or issues involved in the current legal issue that affect decision-making. ${ }^{67}$ This Article finds a much broader connection between past experiences and decisions about whether to pursue resolving legal issues, even when past experiences have little or no relationship to the civil justice issue at hand. ${ }^{68}$ Additionally, this Article finds that past experiences and perceptions of criminal justice events and circumstances are a key factor in civil justice decision-making.

\section{B. EXISTING RESEARCH ON RACE AND TRUST}

This Article further implicates the way race affects how low income individuals access legal services for civil justice problems. The key finding is that low levels of trust in institutions (both legal and non-legal) play a significant role in why black respondents do not pursue help through the justice system. The same is not true for white respondents, who were more likely to trust institutions. This finding is consistent with a long line of research about race and trust. In this Subpart, I provide a brief overview of this research

65. Id. at $117^{-19}$.

66. Sandefur finds that the following five reasons were most commonly invoked in decisionmaking about pursuing legal action: (1) "[s] hame and [e]mbarrassment;" (2) "[u]nfavourable [b]alance of [p] ower" in the relationships with persons or organizations with whom they have a grievance; (3) fear based on past experiences with parties in the relationship with whom a grievance arose; (4) gratitude towards a party with whom a grievance arose based on past experiences with the party; and (5) "[f]rustrated [r]esignation" about the ability to solve a problem based on "past experiences of . . f failure in trying to resolve similar problems." Id. at 123-26.

67. Id.

68. Sandefur has released a preliminary report from a study she conducted utilizing a random sample of adults in a middle-sized midwestern American city that mirrors the 1994 American Bar Association study on civil justice needs. SANDEFUR, supra note 7 . However, unlike the ABA study and this study, Sandefur's Community Needs and Services Study is not limited to low and moderate income people but instead randomly samples individuals from all income levels in one midwestern city. Id. at 5 . In this survey, Sandefur found that one of the key reasons people do not seek help for civil legal problems is that they do not consider the problems legal in nature and do not feel that they need help. Id. at 14. Sandefur's finding is not broken down by income or race, so it is difficult to know whether it applies to low income residents. In the study that is the subject of this Article, the semi-structured interviews asked respondents about all of the civil legal problems they were experiencing (whether they considered them legal or not), but then focused specifically on problems that they did consider legal. Thus, the key difference between this study and Sandefur's is that I specifically analyzed problems that respondents did identify as potentially legal in nature. Of course many respondents experienced other issues they did not consider legal, but my analysis did not focus on those issues. In other words, the focus of the inquiry for this study was how respondents thought about and dealt with problems that they identified as potentially legal problems. 
in order to put the findings from this study into the context of the broader research about race and trust.

Before 1985 , social science research was mostly void of research about trust. However, in 1985 , David Lewis and Andrew Weigert brought important attention to the conception of trust in the social sciences and spurred a large line of trust research. ${ }^{69}$ Lewis and Weigert noted that trust had been largely neglected by researchers but that it is an important concept to study because it "function [s] as a deep assumption underwriting social order." 70

Since Lewis and Weigert's article, social scientists have studied trust using a variety of methods and in a number of different dimensions. For example, political scientists have studied trust and confidence in government institutions using quantitative methods. ${ }^{71}$ These studies often use a scale that assesses evaluative orientations towards the national government. Specifically, theorists have measured "'trust in government,' 'confidence,' 'political cynicism,' 'disaffection,' and 'alienation." "72 Several political scientists have argued that institutional trust and trust in the political process are important because trust encourages political participation and discourages engagement in system-challenging behavior.73

Many researchers have examined differences in trust of institutions by race. 74 "According to the political scientist Eric Uslaner: 'Race is the life experience that has the biggest impact on trust." 75 Research shows that blacks are significantly less likely to trust than whites, that the racial differences between these two groups are the starkest, and that the "black-white gaps in trust cannot be accounted for by class differentials." $7^{6}$ In contrast, it has been found that after controlling for education level, the differences between Hispanics and whites regarding trust decline to insignificance. Thus, a large

69. J. David Lewis \& Andrew Weigert, Trust as a Social Reality, 63 SOC. ForCeS 967 (1985).

7o. Id. at 967 .

71. See TOM R. Thler \& Yuen J. HuO, Trust in the Law: Encouraging Public COOPERATION WITH THE POLICE AND COURTS 104 (2002).

72. Id. (quoting Jack Citrin and Christopher Muste's 1999 study about trust in government).

73. See Margaret Levi \& Laura Stoker, Political Trust and Trustworthiness, 3 ANN. REV. POL. SCI. $475-76$ (2000).

74. One interesting line of study is the connection between race, trust, and healthcare. As Barak Richman discussed in his article about Medicaid's failure to improve health outcomes, several studies have shown that blacks are less trusting of healthcare workers and the healthcare system than whites. Barak D. Richman, Behavioral Economics and Health Policy: Understanding Medicaid's Failure, 90 CORNELL L. REV. 705, 735 (2005). Richman noted that these findings may be connected to other studies that have found that blacks were less likely to seek healthcare and adhere to healthcare plans. $I d$. at $73^{6}$. Other studies have found that less trusting patients exhibit poorer health behaviors and are less likely to seek necessary care. Id. at 734 .

75. Sandra Susan Smith, Race and Trust, 36 ANN. REv. SoC. 453, 454 (2010) (quoting ERIC M. USIANER, THE MORAL FOUNDATIONS OF TRUST 91 (2002)).

76. Id. 
majority of research on racial differences in trust (including this Article's study) focuses specifically on blacks and whites. 77

Blacks are widely believed to view law enforcement and other legal institutions with greater distrust than whites. $7^{8}$ There are also several studies comparing generalized trust differences between blacks and whites with similar results. One study found that while " $51 \%$ of whites reported that most people are untrustworthy, $81 \%$ of blacks [reported that] most people [were] untrustworthy." 79 Additionally, "[b]lacks were also far more likely than whites to report that people are unfair $(61 \%$ versus $32 \%)$." 80 Further, Uslaner found that blacks were "less likely to report generalized trust compared with whites, by between 9 and 22 percentage points." 81 Finally, the Pew Research Center's report on trust shows that $41 \%$ of whites report high trust, as compared to $20 \%$ of blacks, and that just $32 \%$ of whites reported low trust, compared to $61 \%$ of blacks. $^{82}$

There are several theories that have been invoked to explain the blackwhite disparity in trust. One line of research focuses on neighborhood-based social processes. Extensive work has been done on why and how blacks have ended up living, disproportionately, in neighborhoods with high disorder rates. ${ }^{83}$ Neighborhood disorder, both social and physical, ${ }_{4}$ provides the structural roots for pervasive fear and distrust. ${ }^{8}{ }_{5}$ Researchers have found that

77. See, e.g., id.

78. For research that supports this view, see Richard R.W. Brooks, Fear and Faimess in the City: Criminal Enforcement and Perceptions of Fairness in Minority Communities, 73 S. CAL. L. REV. 1219 , 1221 n.6 (2000) (citing Julian V. Roberts \& LORETTA J. STALANS, Public Opinion, Crime, and CRIMINAL JUSTICE 1 27-54 (1997); KATHERYN K. RUSSELL, THE COLOR OF CRIME: RACIAL HOAXES, White FEAR, Black Protectionism, POlice Harassment, AND OTHER MACROAGgressions 26-46 (1998); William J. Stuntz, Essay, Race, Class, and Drugs, 98 COLUM. L. REv. 1 795, 1797 n.6 (1998)).

79. Smith, supra note 75 , at 456 (citing Tom W. Smith, Factors Relating to Misanthropy in Contemporary American Society, 26 SOC. SCI. RES. 170, 186 (1997)).

8o. $\quad I d$.

81. Id. (citing USLANER, supra note 75, at 107 n.26).

82. Paul Taylor et al., Pew Research Ctr., Americans and Social Trust: Who, Where AND WHY (n.d.), http://pewresearch.org/assets/social/pdf/SocialTrust.pdf.

83. See, e.g., Massey \& Denton, supra note 38; William Julius Wilson, The Truly Disadvantaged: THe InNer City, THE UnderClass, ANd Public Policy (1987); Robert J. Sampson, Racial Stratification and the Durable Tangle of Neighborhood Inequality, 621 ANNALS AM. ACAD. POL. \& SOC. SCI. 260 (2009).

84. Social disorder is defined as "behavior usually involving strangers and considered threatening, such as verbal harassment on the street, open solicitation for prostitution, public intoxication, and rowdy groups of young males in public." Robert J. Sampson \& Stephen W. Raudenbush, Systematic Social Observation of Public Spaces: A New Look at Disorder in Urban Neighborhoods, 105 AM. J. SOC. 603, 603-04 (1999). Physical disorder is defined as "the deterioration of urban landscapes, for example, graffiti on buildings, abandoned cars, broken windows, and garbage in the streets." Id. at 6o4.

85. See generally Catherine E. Ross \& John Mirowsky, Disorder and Decay: The Concept and Measurement of Perceived Neighborhood Disorder, 34 URB. AFF. REV. 412 (1999); Sampson \& Raudenbush, supra note 84 . 
" $[\mathrm{t}]$ o the extent that trust assumes specific racial hues, it is because the social factors and processes that create and maintain durable tangles of neighborhood inequality are stratified by race-specifically, blacks are disproportionately exposed to neighborhoods and communities of concentrated disadvantage. $" 86$

Another key explanation for ethnoracial differences in trust is historical and contemporary experiences of discrimination. Orlando Patterson argues that "[p]olitical influence and attendant gains lead to a realistic perception of political effectiveness, which reinforces political trust, and the tendency to be more politically active. The opposite set of linkages operates with persons from lower [socioeconomic status] groups." ${ }_{7}$ Blacks are most disadvantaged by these linkages, "a finding that is disturbingly predictable given the incentives to distrust built into the history of slavery, semifeudal sharecropping, segregation, and disenfranchisement." 88

Indeed, research shows that blacks experience discrimination across a variety of institutional contexts. Notably, blacks are more likely than whites to experience biased treatment in the judicial system. ${ }^{89}$ Groups who are discriminated against "are also more likely to perceive that they are discriminated against across multiple institutional contexts." 90 The findings from the DOJ's recent inquiry into the police and court practices of Ferguson, Missouri only add to the hypothesis that actual discrimination in a variety of law-related settings (rationally) cause blacks to be distrustful of such institutions.9' The report found: "Ferguson's approach to law enforcement both reflects and reinforces racial bias, including stereotyping. The harms of Ferguson's police and court practices are borne disproportionately by blacks, and there is evidence that this is due in part to intentional discrimination on the basis of race." $9^{2}$

Thus, because of blacks' perception93 "that they are treated poorly and unfairly, ... they distrust." 94 Tom Tyler and Yuen Huo conducted several studies about perceptions of fairness and procedural justice. 95 Among other findings, Tyler and Huo found that blacks "were more likely to perceive that

86. Smith, supra note 75 , at 460 .

87. Orlando Patterson, Liberty Against the Democratic State: On the Historical and Contemporary Sources of American Disinust, in DEMOCRACY AND TRUST 1 51 , 196 (Mark E. Warren ed., 1999 ).

88. Mark E. Warren, Introduction, in DEMOCRACY AND TRUST, supra note 87, at 1,11 .

89. See e.g., DAvid Cole, No Equal. Justice: RACE AND Class IN THE AMERICAN CRIMINAL JUSTICE SYSTEM 4-6 (1999); WESTERN, supra note 1 7, at 34-43.

9o. Smith, supra note 75 , at $45^{8}$.

91. See supra note 12.

92. CIVIL RIGHTS DIV., supra note 12 , at 4 .

93. Indeed, as the Ferguson Report details at great length, blacks' perceptions that they are treated poorly by the justice system are likely, at least in some contexts, not just perception but reality. Id.

94. Smith, supra note 75 , at 458 .

95. See, e.g., TYLER \& HUO, supra note 71 , at $47-96$. 
the quality of decision making and the quality of the treatment they received [in court] were poor," and "they were also less likely to understand the actions taken by legal authorities in their case $[s] . " 9^{6}$

There is also evidence to show that black parents are more likely to prepare their children for bias.97 Preparing children for bias "reflects parents' efforts to inform their children about the extent and nature of discrimination faced by members of their in-group as well as strategies to effectively cope with discriminatory treatment. ${ }^{8} 8$ Further, parents who receive bias socialization as children are more likely to prepare their own children for bias and are also more likely to promote racial mistrust towards out-group members.99 Additionally, parents who perceive that their children receive unfair treatment by adults or other children because of race are more likely to promote mistrust in their children. ${ }^{100}$

In addition to the roots of mistrust, there has been significant research about the consequences of different trust levels, including several qualitative studies. Though research has shown that high trusters risk being taken advantage of by the untrustworthy, there are many risks associated with being a low truster as well. ${ }^{\circ}$ Most relevant to this study is that low trusters are more likely to be cautious when dealing with others and are less likely to take risks. ${ }^{102}$ As Sandra Smith notes, the predisposition of being a low truster "sets in motion a vicious cycle. It reduces their willingness to engage in social interactions that might result in more rewarding, cooperative relationships, which might also improve their ability to distinguish accurately between the trustworthy and the untrustworthy, eventuating in an inclination to trust and cooperate."103

Several researchers have used qualitative methodology to study trust in the black community. Gerald Suttles has found that blacks were the most likely among any of the ethnic groups he studied to distrust each other. ${ }^{104} \mathrm{He}$ notes that blacks "remain the most estranged from one another. Anonymity and distrust are pervasive, and well-established peer groups are present only among the adolescents." ${ }^{\circ} 5$ Additionally, Elijah Anderson argues that

96. Smith, supra note 75 , at $45^{8}$ (citing Tyler and Huo's 2002 study).

97. See, e.g., id. at 462 .

98. Id.

99. Diane Hughes \& Lisa Chen, When and What Parents Tell Children About Race: An Examination of Race-Related Socialization Among African American Families, 1 APPIED DEVELOPMENTAL SCI. 200, 211 (1997).

100. Id.

101. Smith, supra note 75 , at 468 .

102. Id.

1 03 . SANDRA SUSAN SMITH, LONE PURSUIT: DISTRUST AND DEFENSIVE INDIVIDUALISM AMONG THE BLACK POOR 37 (2007).

104. GeRALD D. SUTTLES, THE SOCIAL ORDER OF THE SlUM: ETHNICITY AND TERRITORY IN THE INNER CITY 9 (1968).

105. Id. 
widespread distrust among black poor individuals, particularly those who live in neighborhoods of concentrated poverty, has led to individualistic approaches to handling conflicts and gaining respect that are based on violence and retribution. ${ }^{106}$ This, he argues, has contributed to the high rate of violent crime in these areas. ${ }^{107}$

Further, in Frank Furstenberg's ethnography, he found that distrust among poor black neighbors led to individual approaches to childrearing in poor black neighborhoods. ${ }^{108} \mathrm{He}$ found that the more "successful" parents in these neighborhoods were those who sought social and institutional support outside of the neighborhood and isolated themselves from neighbors, whom they felt would have detrimental effects on their children. ${ }^{109}$ However, less successful parents also socially isolated themselves, but did not seek support outside of the neighborhoods. ${ }^{10}$ Generally, distrust among parents in the neighborhood led to isolation and to individualistic approaches to parenting. ${ }^{11}$

Finally, Sandra Smith's study of distrust in the context of employment is particularly useful for understanding the behavior of respondents in this Article's study."12 Smith's ethnographic study of 105 black men and women in Michigan found that jobseekers and jobholders in these neighborhoods hold a mutual distrust that thwarts cooperation and contributes to the pervasive unemployment problem among poor blacks."13 Jobholders were reluctant to refer their friends and relatives to job openings, noting that the jobseekers in their networks were unmotivated and potentially irresponsible on the job. ${ }^{14}$ Thus, they were concerned that they would jeopardize their own reputations with employers if they referred these people to jobs. These jobholders "ranted about the importance of self-reliance" and individualism, thus justifying their resistance to help others. ${ }^{1} 5$

Additionally, a substantial number of jobseekers were reluctant to ask for help in finding a job from jobholders in their network because they "feared falling short of expectations or being maligned by their personal contacts for being jobless" in the first place. ${ }^{16}$ As a way of "justify[ing] their reluctance to

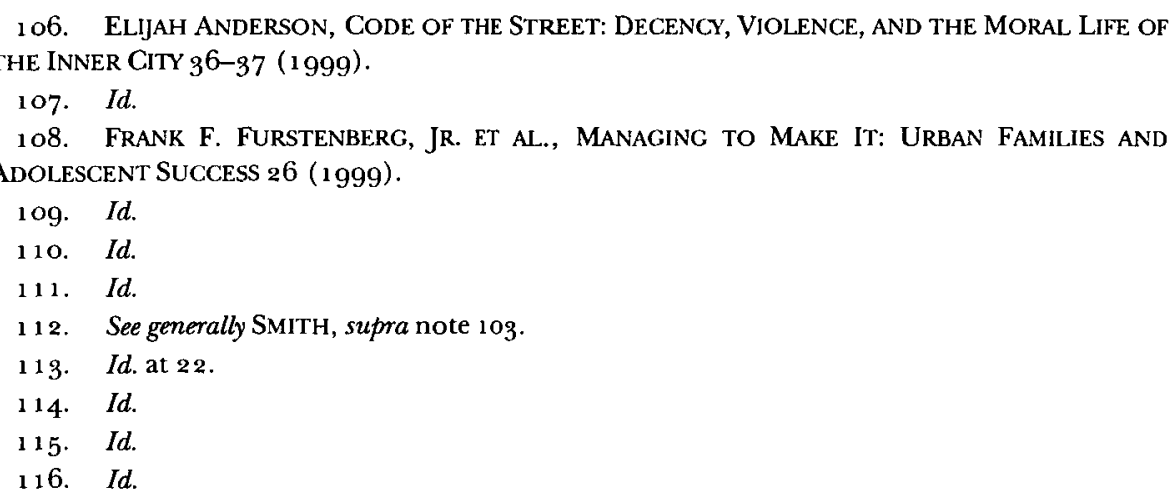


use personal contacts, job-seekers embraced individualism" (what Smith terms defensive individualism), and they utilized much less effective job search methods in order to be independent. ${ }^{117}$ The discourses of personal responsibility, self-sufficiency and moral shortcomings that surrounded them, and their knowledge of the negative perceptions others had of their joblessness, made them reluctant to ask for help and also distrustful of both themselves and intermediaries. ${ }^{118}$

This Article builds on the work of this existing research by examining another context-the civil justice system and its utilization-in which trust is a significant factor. I show how differences in trust levels of blacks and whites ultimately lead to differential behavior when faced with civil justice problems.

\section{DATA AND METHODOLOGY}

\section{A. QUALITATIVE METHODS}

Several prominent legal scholars have utilized in-depth interviews for high impact studies about questions of law and legal culture."19 In-depth interviews enable researchers to engage in "process tracking," which helps to "discern how processes emerge and evolve." 120 They are seen as advantageous over surveys for instances where researchers are attempting to understand "the experience[s] of individuals within social contexts" and to include

117. Id.

$118 . \quad I d$

1 19. There are, in fact, far too many important qualitative studies in many fields of law to name. Some limited examples in a vast field include: ElLICKSON, supra note 48; Catherine R. Albiston, Bargaining in the Shadow of Social Institutions: Competing Discourses and Social Change in Workplace Mobilization of Civil Rights, 39 LAW \& SOC'Y REV. 11 (2005) (drawing on 24 interviews with workers who negotiated contested leaves under the Family and Medical Leave Act to examine how social institutions influence workplace mobilization of rights under the Act and how rights under the Act operate in practice and interact with other normative systems to construct the meaning of leave); Angela Littwin, Beyond Usury: A Study of Credit-Card Use and Preference Among Low-Income Consumers, 86 TEX. L. REV. $45^{1}$ (2008) (interviewing 50 low income women about their experiences and preferences for usury regulations and then using the findings and suggestions of the women to advocate for modifications to credit cards that could serve the needs of both low income women and creditors); Macaulay, supra note 49 (interviewing 1 oo lawyers in Wisconsin to better understand the impact of consumer protection laws, finding that lawyers tend to know little about the precise aspects of consumer protection law and instead rely on general norms of fairness and incentives for themselves when handling cases, and discussing the implications of these findings); Ronald J. Mann, Explaining the Pattern of Secured Credit, 110 HARV. L. REV. 625 (1997) (utilizing interviews with more than 20 borrowers and lenders in various sectors of the economy to better understand how they decide whether to engage in a secured or unsecured transaction); and Morrill et al., supra note 57 (utilizing both quantitative methods and qualitative interviews to analyze ethnoracial patterns in youth perceptions and responses to rights violations and to advance a new model of legal mobilization).

1 2O. MICHÈLE LAMONT \& PATRICIA WHITE, WORKSHOP ON INTERDISCIPLINARYSTANDARDS FOR SYSTEMIC QUAI.ITATTVE RESEARCH 10 (n.d.), http://www.nsf.gov/sbe/ses/soc/ISSQR_workshop_ rpt.pdf. 
subjective experiences. ${ }^{121}$ In-depth interviews enable researchers to gather data about "the cultural understandings actors bring to social experience, interactions, and institutions." 122

In-depth interviews are also an important tool for gathering data that individuals may be reluctant to share. Interviews, particularly those conducted in respondents' homes, allow researchers to build rapport and trust with the participants during the interview. ${ }^{123}$ This may increase the chances of obtaining and understanding potentially embarrassing information, information respondents deem personal, or information respondents are concerned about sharing for fear of retaliation. ${ }^{124}$ Such information can be key in helping to explain behavior, which in turn can aid in improved policy design. ${ }^{125}$

The study described in this Article sought to understand the social contexts and experiences that contribute to inaction among poor people when experiencing civil legal issues. Inaction is a behavior large survey studies have indicated is common. ${ }^{126}$ In-depth interviews are the ideal methodology because the goal is to explain the social and cultural mechanisms behind behavior that existing survey data has already uncovered. The cognitive and cultural constraints raised by respondents in this study would have been difficult to capture in a survey. Many of the motivations and descriptions of behaviors required extensive explanations by the respondents. They would have been difficult for the respondents to whittle down to one or two sentences, let alone a multiple-choice answer. Open-ended questions, answers, and follow-up questions were needed to better understand respondents' underlying cultural beliefs, attitudes, and resulting behaviors when faced with civil legal problems.

Additionally, several of the unexpected explanations of inaction that this study uncovered have been absent from existing access-to-justice literature. Thus, a survey that forced respondents to select a predetermined answer would not have captured the cultural explanations for respondents' behaviors because it is unlikely such explanations would have been included in the survey. Finally, because of the sensitive nature of the questions asked, building trust between the interviewer and the respondent was vital to help insure complete explanations of behavior and beliefs. Indeed, some respondents were resistant to discussing issues of race and class, sometimes waiting until

121. Id.

122. Id.

123. See Littwin, supra note 119 , at 504 (discussing the means by which the author worked to build trust between the interviewer and the interviewee in order to obtain sensitive financial information).

124. See id.

125. See id. at 503-05 (discussing the means by which the author worked to build trust between the interviewer and the interviewee in order to obtain sensitive financial information).

126. See, e.g., CONSORTIUM ON Legal SERvs. \& THE PUB., supra note 3. 
the second half of the interview when they presumably felt more comfortable with the interviewer to do so. It is unlikely this Article's study could have been completed effectively using conventional survey techniques.

\section{B. SAMPLE SELECTION}

The data in this Article's study consist of transcripts and field notes from in-depth qualitative interviews with 97 residents of public housing communities in Cambridge, Massachusetts. ${ }^{127}$

Interviews were primarily conducted between 2007 and 2008. I sampled from public housing communities to ensure that the sample was comprised of individuals who are poor (living below $80 \%$ of the area median income) and that the sample did not contain convicted felons. ${ }^{128}$

I chose a heterogeneous, nonrandom sampling technique due to concerns about reaching low income respondents and concerns about building rapport. ${ }^{29}$ Thus, I recruited participants in several ways, constructed to increase the likelihood that they would trust me and be forthcoming about their behaviors and motivations, as well as to increase the likelihood that they would follow through on completing the interview at the scheduled time and location. I initially contacted the main Housing Authority office in Cambridge, Massachusetts and requested access to public housing buildings and communities and permission to post fliers advertising my study in these communities. This office directed me to contact managers for each individual community or building.

I contacted the managers, all of whom ultimately gave me permission to recruit in their communities. I met with six of the managers in person, at their

127. One of the limitations of qualitative research is that the sample is not a national random sample. When deciding where to sample for this research question, I considered several cities. For example, Boston was considered, but because it has a history of particularly tense community-police relations, it was ultimately rejected. See generally Anthony A. Braga et al., Losing Faith? Police, Black Churches, and the Resurgence of Youth Violence in Boston, 6 OHIO ST. J. CRIM. L. 141 (2008). Such tense relations may affect how respondents view the justice system as a whole. I also sought a city that did not have innovative civil justice programs such as community courts, and I sought a community where I had connections to city officials and more potential for access to respondents. Cambridge met these criteria.

1 28. Convicted felons are not permitted to live in public housing communities, and background checks are conducted. While convicted felons are an interesting subset to study, initial analysis suggested that criminal justice experiences and observations have a significant effect on civil justice utilization. Thus, convicted felons would likely be a group who with special considerations when civil legal issues present themselves. This may be an interesting follow-up study, but for the purposes of this study's research questions, convicted felons were intentionally left out of the sample.

1 29. See, e.g., Kathryn Edin \& Laura Lein, Work, Welfare, and Single Mothers' Economic Survival Strategies, 62 AM. SOC. REV. 253, 254-55 (1997) (noting difficulties in obtaining reliable information from poor respondents who "had no personal introduction to us," and thus, in a later study, "recruit[ing] welfare-reliant mothers by asking individuals from nongovernmental community organizations and local institutions to introduce us to welfare recipients with whom they had established some rapport and testify to our trustworthiness"). 
request. Some of the managers asked me extensive questions about confidentiality and any relationship I may have had to the police. I also contacted the heads of any tenant councils in individual communities. I met with five of them in person, all of whom promised to vouch for me and spread the word about my study. Additionally, I engaged in limited snowball sampling, a standard technique for sampling populations that are difficult to reach through randomized methods. ${ }^{30}$ The limited snowball sampling consisted of asking respondents if they had any friends living in public housing who might be interested in being interviewed. I paid respondents \$10 for each referral, and I only allowed one referral per respondent. I did not ask respondents who were referred via snowball sample for further referrals.

The sample was limited to respondents between the ages of 18 and 65 . I sought to interview roughly equal numbers of men and women as well as black and white respondents. I ultimately interviewed 21 self-identified black males, 26 self-identified white males, 24 self-identified black females, and 26 selfidentified white females.

This Article's study is not meant to prove or disprove existing theories about access to civil justice, but rather to give an in-depth account of behavior related to civil legal problems of a relatively heterogeneous (in terms of sex and race) group of poor public housing residents. The analysis will show that much of what the respondents say confirms existing knowledge that inaction is a common response of the poor to civil legal problems. ${ }^{13}{ }^{1}$

The respondents' accounts reveal motivations for inaction that existing approaches generally neglect, or only begin to address. The overall result is a complex set of personal accounts that can lend crucial qualitative grounding to other existing and future representative studies about access to civil justice for the poor. The aim of the sampling strategy and study is to illuminate and

1 go. See, e.g., Jean Faugier \& Mary Sargeant, Sampling Hard to Reach Populations, 26 J. ADVANCED NURSING 790 (1997); Sarah H. Ramsey \& Robert F. Kelly, Using Social Science Research in Family Law Analysis and Formation: Problems and Prospects, 3 S. CAL. INTERDISC. L.J. 63 i (1994). For examples of research using snowball samples to study legal issues, see Elizabeth Chambliss \& David B. Wilkins, The Emerging Role of Ethics Advisors, General Counsel, and Other Compliance Specialists in Large Law Firms, 44 ARIz. L. REV. 559, $5^{61}$ (2002) (discussing "the emerging role of compliance specialists in large law firms" using a snowball sample); Mariano-Florentino Cuéllar, Refugee Security and the Organizational Logic of Legal Mandates, 37 GEO. J. INT'L L. $5^{83}, 5^{86}$ (20o6) (using a snowball sample to obtain one of three sets of interviews on "the legal, political, and bureaucratic dynamics affecting refugees' physical security"); and Littwin, supra note 119 , at $5 \mathrm{O}_{4}-\mathrm{O}_{5}$ (using a snowball sample of women living in public housing to obtain information about their credit card usage and behavior and their thoughts about credit cards). For more about the difficulty and expense of reaching low income populations, see Michael S. Barr, Detroit Area Study on Financial Services: What? Why? How? LAW QUADRANGLE NOTES, Summer 2005 , at 72.

131. See, e.g., CONSORTIUM ON LEGAL SERVS. \& THE PUB., supra note 3; see also infra Part IV. 
understand rather than to predict or determine causation. ${ }^{13^{2}}$ This is the dominant strategy used among analytical sociologists. ${ }^{133}$

\section{DATA COLLECTION}

This study's interviews were conducted after phone contact with potential respondents to ensure they qualified for the study. All respondents received $\$ 3$ o for a roughly 1.5 -hour interview. If the interview went more than $3^{\circ}$ minutes over the predicted 1.5-hour time, respondents received an additional $\$ 10$ for their time. It was not uncommon for respondents to ask us to stay for a meal, to cry when describing past experiences with the justice system or other institutions, or to refuse the interview compensation because the interview felt "therapeutic." 134

All but eight of the interviews were conducted in the respondents' homes. Because of the sensitive nature of the data being collected, it was particularly important to conduct the interviews in non-public places to avoid fears that others would overhear the conversation. The interviews that were not conducted in respondents' homes were conducted in recreation rooms in public housing buildings that were empty at the time of the interview.

I hired and trained a research assistant to help conduct 20 of the interviews and to assist with general administrative tasks related to the project. I trained her in skills such as developing rapport with respondents, probing for follow-up answers, and going through the consent form with respondents. The research assistant first attended two interviews that I conducted. I then attended her first two interviews and gave her extensive oral and written feedback. ${ }^{135}$

At the beginning of each interview, respondents signed a consent form that, among other things, summarized the study and potential risks and benefits to the respondent, detailed the confidentiality measures taken to protect respondent identity, and allowed the interview to be recorded..$^{1}{ }^{6}$ The

132. JULIET CORBIN \& ANSELM STRAUSS, BASICS OF QUALITATIVE RESEARCH: TECHNIQUES AND Procedures for DeVEloping Grounded THEORY 48, $159-60$ ( $3 \mathrm{~d}$ ed. 2008).

133. See Mario Luis Small, Causal Thinking and Ethnographic Research, 119 AM.J. SoC. 597, 599 (2013).

134. Out of the 97 interviews, 16 of the respondents indicated that they did not want to accept the interview compensation. My research assistant and I insisted respondents accept the money, and all eventually did so.

135. I have been an interviewer in several large-scale qualitative data studies and was trained as an interviewer by Dr. Kathryn Edin. Dr. Edin is The Bloomberg Distinguished Professor of Sociology at Johns Hopkins University and is renowned internationally for her research utilizing in-depth interviews.

136. This study was approved by the Institutional Review Board ("IRB") of Harvard University. The approval required strict confidentiality measures to be taken and all names and identifying information to be changed. Both of these measures have been taken for the data presented in this Article. Additionally, all data (voice recordings and transcriptions) were securely stored, as required by the IRB. 
interviews were semi-structured-we used a protocol to ensure that we pursued a consistent set of themes and questions, but also explored additional topics as they arose during the course of the interviews.

The interview protocol began with a "warm-up" section that invited respondents to tell us about themselves, their family, and the general path and timeline of their life. Demographic data was also collected in this section.

The protocol then covered several different themes and issues. One section of the protocol focused on neighborhoods and the police. This included questions about respondents' relationships with their neighbors, experiences with the police as it related to both their neighborhood and outside of their neighborhood, perceptions about crime both within and outside of their neighborhoods, and their perceptions of how the police related to the larger legal system.

Another section of the protocol focused on respondents' experiences with social services and public institutions. We asked questions about these experiences before we asked any questions about the law or legal institutions so as to not bias respondents to think about or talk about these experiences in the context of the law if they were not so inclined. This section asked about experiences receiving welfare, how respondents perceived they were treated when and if they did receive it, whether respondents received other government assistance and their experiences with these programs. This section also included questions about experiences with schools and churches.

The protocol contained a section that was designed to assess respondent's knowledge of the justice system. This section contained questions about the different types of courts in the United States (everything from the United States Supreme Court to small claims court), questions about how one could bring a case to various types of courts, how one can access lawyers and for what types of cases, and questions about how court cases are financed. The section also contained questions that sought to understand how, if at all, the respondents thought courts and prisons were connected. Respondents were also asked a series of questions about their perceptions of justice and fairness, both broadly and within the American justice system.

Several sections of the protocol dealt directly with past experiences with civil justice issues. Before beginning this series of questions, we asked each respondent to either fill out a civil legal issues checklist or have the interviewer read it aloud and fill it out for him.'37 The checklist was almost exactly the same as the one used by the American Bar Association's quantitative accessto-justice study that found socioeconomic disparities in civil justice utilization. ${ }^{13^{8}}$ Respondents were asked about how they handled each potential civil justice problem they indicated they had experienced, what they believed their various options were, and about their decision-making process about

137. See infra Appendix.

138. See CONSORTIUM ON Legal SeRvs. \& THE PUB., supra note 3. 
how to handle (or ignore) the problem. We also asked respondents about their knowledge of and perceptions of any justice involvement of their family and/or friends. Towards the end of the interview, respondents were asked a series of hypothetical questions about civil legal problems and how they might proceed in various situations. These questions were particularly useful for respondents who had experienced very few or no civil justice problems.

Throughout the interview, respondents were asked questions that were meant to elicit responses about trust. At first, these questions did not explicitly mention the word trust. Towards the end of the interview, we asked respondents questions about their childhood and trust, as well as the direct question: "Do you trust courts?" Knowing that the word "trust" can mean many things to many people, we also asked respondents to define what trust meant to them and did not guide them in any one direction. Finally, at the end of the interview, respondents were asked for their own policy recommendations for the justice system as a whole, and what, if anything, they would change about it as it currently exists.

\section{DATA ANALYSIS}

All of the interviews were transcribed, word-for-word, by a professional transcriber. I then loaded all of the transcribed interviews into a standard qualitative data analysis program (AtlasTi). I then followed a standard qualitative data coding and analysis procedure. I began with "open coding," which meant assigning descriptive codes to each line of the transcribed interview. ${ }^{39}$ After this process was completed, I moved on to "axial coding," a process in which codes were aggregated into larger concepts and themes and then checked against the interview data to confirm that the themes accurately represented interview responses. $4^{\circ}$ At this point, I developed a detailed codebook and revisited the transcripts, coding into these larger themes and concepts. Finally, after I felt comfortable with these larger themes and concepts that had emerged, I engaged in conceptualization, which includes an iterative process of mapping and remapping concepts and themes, their contents and boundaries, and their relationships and interrelationships. At several points during this process I stopped to make sure that the theory I was building was constructed from the data, and eventually a coherent narrative and theory emerged that was linked directly to the data. ${ }^{14}$

\section{E. DATA PRESENTATION}

In line with the requirements of the Internal Review Board and the confidentiality agreement that respondents signed, I made every effort to protect the identity of respondents. At the stage of initial contact, each

139. See CORBIN \& STRAUSS, supra note 132, at 195.

140. See id. at 198-99.

141. See generally id. 
respondent was assigned a unique identification number, which was included on their transcripts and data file. A name (not associated with the respondent's actual name) was assigned to each unique code number to ease data presentation and eliminate potential confusion. I omitted potentially identifying information from all data presentation, such as exact addresses and exact places of employment.

In presenting data in this Article, I primarily used adjectives such as "most," "many," and "some" to convey the prevalence of a theme across interviews, rather than reporting exact percentages of prevalence. In qualitative data, presentation of exact numbers can lead to a false sense of precision of the data. Further, these percentages do not take into account the strength of people's statements.

I used the word "most" when the vast majority of respondents in a given referent group (such as black respondents) indicated a specific viewpoint or theme. I used the word "many" when roughly half of the referent group referred to a position or theme, and the word "some" when a theme or idea was not representative of a group as a whole but was shared by several people and thus suggested a potentially important pattern. All findings presented in this Article were supported by multiple respondents, and no outlier viewpoints were presented, unless indicated as such. In some instances, I did report exact percentages or proportions of respondents who expressed a certain viewpoint because I believed these numbers would be helpful to the reader. This was technically possible to do for more themes, but I refrained from doing so because of the limitations and potential for misunderstanding such presentation of qualitative data can promote.

\section{RESULTS}

The results of my analyses are described in two Subparts. In Subpart A, I discuss the explanations for inaction that emerged across all respondents. ${ }^{14^{2}}$ In Subpart B, I describe the explanations for inaction that differed between white and black respondents.

\section{A. SHARED EXPLANATIONS FOR INACTION}

The explanations for inaction that were shared across the respondents' racial groups fell into four general categories that were interrelated. First, most respondents believed that the criminal and civil justice systems were one in the same, and negative past experiences with, and perceptions of, the criminal justice system made them resistant to seeking help for civil problems. Second, respondents (most referring to the criminal justice system) believed that the justice system is one in which justice can be bought, and thus, if one does not have the money to pay for an expensive lawyer, seeking out formal

142. This Part details only explanations for inaction that were common among respondents. See supra note 16 . 
legal help is unlikely to resolve the issue. Third, negative past experiences with public institutions (both legal and non-legal) led respondents to want to avoid similar negative experiences, and they perceived involving themselves with the legal system as an experience that would reproduce those negatives feelings. Finally, in part as a way to make sense of their past perceptions of, and experiences with, the criminal justice system and other public institutions, many respondents developed personal narratives as self-sufficient citizens who take care of their own problems and stay "out of trouble." Seeking help from the legal system was counter to this identity.

1. "To Me It's All Law and Courts and Bad": Criminal and Civil Justice Confusion

During the first few interviews I conducted, I noticed that even though my interview questions focused almost entirely on civil justice, respondents answered with examples from criminal justice experiences and perceptions. After a few more interviews, it became clear why: most respondents did not know the difference between the criminal and civil justice systems, or even about the existence of two different systems with different players and processes. Respondents were asked a specific question about the differences between the civil and criminal justice system, and $78 \%$ of the respondents said they did not know. Responses such as the following were typical:

I'm not really sure. To me it's all law and courts and bad. Stay away from the law, that is my MO. It's good advice.

$$
\text { -Lynn }
$$

I think it has something to do with what the crime is, but it's the same lawyers and judges and courts. It's a sorting, but a sorting why? I'm not so sure.

\section{- Chris}

It's about all the same. They come up with fancy names and such so I can't understand, but, um . . . it's really the same. All the same.

-Isaiah

One plausible explanation for this confusion was that respondents did, as a practical matter, understand the difference between the two systems of justice but simply were not familiar with the term "civil" justice. However, asking follow-up questions confirmed that the confusion was not just around the word "civil." Respondents were asked how they would go about finding a lawyer if they were being evicted, for example, and many respondents said they would have to seek help from a public defender:

Well, if I really needed a lawyer against my landlord I could get one of those public defenders for free. I wouldn't want one, but yes they 
are available and they are free. They have to take you. You'd just go right down there to that legal aid and get yourself a public defender.

-Tara

I'm not in the business of going to lawyers, but if I needed to, there are public defenders available for free.

-Valerie

Scholars who study the legal system typically fall into one of two broad camps: those who study the civil legal system and those who study the criminal legal system. These two groups rarely come together at academic conferences; rarely work together on research projects; and, for the most part, see themselves as studying two very distinct systems and bodies of law. While this may be true from a legal standpoint, for most poor respondents there is little difference between the two systems. Court is court. The law is the law. Lawyers are lawyers. Judges are judges.

For most respondents, the majority of their experience with what they consider "the law" had been with the criminal justice system or with hearings that they considered criminal in nature. Even though many respondents had not been charged with criminal activity themselves, ${ }^{143}$ most had a close friend or family member who had been involved with criminal justice in one way or another.

\section{2. "More Money, More Justice"}

Most respondents believed that they were entitled to a free lawyer for any legal problem they had, seeming to confuse the right to a criminal defense attorney with the idea that one has the right to an attorney for any problem. Indeed, $72 \%$ of the respondents in this study believed that they could access a free lawyer to help them resolve any civil legal problem they had. ${ }^{144}$

Unlike scholars and policymakers, the respondents were largely unaware of the long waitlists for civil legal services. A lack of available legal aid lawyers was far from the forefront of most respondents' minds. The problem, in their view, was not access to any lawyer, but that they did not have the money to hire a good lawyer. One respondent, Hilda, repeated "more money, more justice" over and over again throughout her interview. She said:

More money, more justice. I mean it. More money, more justice. It is true. The more money you have for an attorney, whether you are

143. This is likely due to the sample selection of public housing residents. See supra notes $127-28$ and accompanying text.

144. It is important to note that the respondents may not have had accurate views of their ability to access a lawyer. See supra text accompanying note 33. This Article does not argue that increasing funding for lawyers is not important. Instead, it argues that we need to expand how we think about access-to-justice policy and research to include people who never seek out a lawyer but may benefit from some kind of help in addressing a civil legal problem. 
a big case or not, the more justice. If you have more money, they have more time to do the paperwork, investigate, that kind of thing. Oh I can get an attorney, let me tell you. No problem at all. But it won't be one of the good ones.

According to Hilda and most of the other respondents, no matter how much money went to legal aid to increase the number of lawyers available, it would not solve the problem. The issue is not getting a free lawyer; the issue is getting a high quality lawyer, and that, most respondents believed, is only for the rich. The theme that free lawyers are not good lawyers presented in almost all of the interviews. Some of the respondents even provided specific examples of cases in which they believed money for a private lawyer directly affected the outcome of the case, and all of the examples they used were from criminalrather than civil-cases. Amanda, for example, brought up a notorious murder case in Cambridge, Massachusetts: ${ }^{145}$

Well, right now, I am a little on the side that if you have the money, you can get anything you want, even in a courtroom. [Interviewer question: What makes you say that?] Alex Pring-Wilson. His parents are both lawyers, and one of his parents is a district attorney in Colorado. And they have enough money and law experience to keep this going ....

The Pring-Wilson case, a murder case in which the defendant was a white Harvard graduate student with weal thy parents, came up in several interviews as an example of how money can buy justice. One respondent, Gemma, noted:

In the Pring-Wilson case, the money of the parents bought that kid his freedom. Keeping it alive with their lawyers, who are Massachusetts lawyers. Well they were able to buy such good legal representation and enough legal representation to get the first overturned, and now this one could be good. If he were represented by a public defender, he would probably be doing life. I'm not saying anything bad about public defenders. They are like social workers, yeah social workers. Department of, um, DSS workers. They have too many cases. In a way it is and in a way it isn't their fault. It's the system's fault by not having enough money to hire enough social

145. The case of Alexander Pring-Wilson received a great deal of attention in the local media. In April 2003, Pring-Wilson, a white Harvard graduate student, got into a fight with Hispanic male in Cambridge, Massachusetts. John R. Ellement, Jury Deadlocks; DA Vows $3 d$ Trial for Pring. Wilson; Judge Declares Mistrial in Manslaughter Case, Bos. GloBE, Dec. 15 , 2007, at B 1 . Pring-Wilson ultimately stabbed and killed the Hispanic victim. Id. The exact course of events is debated, but Pring-Wilson was found guilty of voluntary manslaughter. Id. The case was in the news again at around the time of the interviews because a law allowing a victim's background to be revealed in court was retroactively applied, and thus, Pring-Wilson was released on bail and granted a new trial. Id. The jury deadlocked on this trial (after this interview was conducted). Id. 
workers and public defenders. And then after a couple of years the good public defenders leave and go into private practice.

"Public pretenders" was a term used to describe public defenders in $35 \%$ of the interviews. Respondents were never asked about this term, but spontaneously used it themselves when describing lawyers. Many respondents discussed specific examples of injustices in the criminal system they or their families had experienced, and these instances reinforced the notion that free lawyers, public defenders, are inadequate. Mary discussed one specific example of how she came to decide public defenders are inadequate:

Two of my son's friends. One of them had a public defender. One had a private lawyer. They both went in there for the same thing. But the public defender one got a lot of time, and the other one got no time. They got caught together, same charges. One got off. That proved it to me. First offense for both of them.

Nia discussed her own experience with the criminal justice system:

Public pretenders, you mean? I was never contacted by my lawyer before my court case. Then, when I got there, he had the wrong file and thought I was someone else. They really suck because they're not getting paid like a regular lawyer would be, so they don't really care.

In contrast to the "bad" public defenders, some respondents talked about the positive experiences they or their family members had with "good" lawyers who cost money. For instance, Travis discussed the experience of his family member:

They don't spend enough time on it. I did have someone in my family with that. He didn't have a public defender. They gave him four to 12 years. They didn't want to give him any deal. The DA wanted murder one. And he, thank god he had money like that, because he ended up spending almost ${ }_{5} \mathrm{~K}$. He would have gotten a lot more time. They came with something like manslaughter, I don't know what it was. They went to trial. The lawyer was pretty good. As a matter of fact the lawyer is a judge now.

Respondents' perceptions of the unjust criminal legal system directly affected their use of the civil legal system. Kenyatha's story is perhaps the best illustration of this. Kenyatha had been separated from her husband for 20 years. At the time of the interview, she had been living with another man and had not talked to her husband, with whom she had two children, in over five years. Because she did not file for divorce, she received no child support or alimony. I probed Kenyatha about why she had not filed for divorce. At first she avoided my questions, simply saying, "I just did not want to get involved" again and again. However, after further questioning she said: 
Honey, to be honest, it pains me; I just could not face those public defenders. You may not believe it, but I just can't. I looked into that divorce stuff myself, honey, it's complicated. Pages and pages of writing, let me tell you. But seeing a public defender for help? Uh uh. No thank you very much. My brother went to jail because of those bastards. Uh uh no thank you. I'll just keep on keeping on. For all I know, I'd go in for a divorce and come out in jail. Really, I'm not seeing no lawyer-ever. That is if I can avoid it. And I can so I will, honey, I can so I will. Maybe I gave up some of my rights regarding him, and some money, but I need to avoid them, honey. That's how it is. No use getting involved.

Kenyatha's perception of the justice system is that for whatever problem she has, she would have to "face" a public defender, and seeing no lawyer is better than seeing a public defender. It was best to just avoid the system at all costs.

Even for those respondents $(46 \%)$ who did not have direct experience with the criminal justice system (either themselves or through family), criminal justice was still what they spoke about when talking about "the law." This may be in part because crime is such a common occurrence in their communities. ${ }^{14}$ However, another significant contributor to respondents' perceptions of the justice system came from television coverage of sensationalized criminal trials and television shows, such as Law and Order.

For example, the interview guide contained questions about the $\mathrm{O} . \mathrm{J}$. Simpson murder case toward the end of the interview. However, it turned out that the majority of respondents brought up Simpson before they were asked questions about him, using his case as an example of how money can buy freedom, even when one is guilty of a heinous crime. ${ }^{147}$ All of the respondents who brought up Simpson believed that he was actually guilty but that his talented lawyers were the reason for the not-guilty verdict:

I think everyone should have the right to good counsel. I mean look at O.J., he got off. I KNOW he did that. It's not a black or white thing, it's about right or wrong. I mean come on, beating her all those years? And I'm so glad he got caught for this thing. So now maybe he'll pay. I think he got off because he paid, I mean he had a good lawyer. I mean if it was me, forget about it, I'd be in jail. I'd have one lawyer to do everything. That's not fair.

146. See generally Lauren J. Krivo \& Ruth D. Peterson, Extremely Disadvantaged Neighborhoods and Urban Crime, 75 SOC. FORCES 619 (1996).

147. Most of these interviews were conducted before O.J. Simpson's second trial for armed robbery and kidnapping (among other felonies) in which he was, indeed, convicted and sentenced to time in prison. 
Look at O.J. He did it. His lawyers is how he got off .... If he had a public defender, he'd be in jail. Everyone should have lawyers like that.

-Malcolm

I'll tell you one thing. And everyone of color hates me to say that. I knew O.J. was guilty.... He was guilty as sin. But he had enough money. And, what did he do, he is a black American that did something that a lot of whites do. But I knew he was guilty. I don't know why but I still feel that. But he got over it because he got the money. ... He was everything to everyone till they heard that phone call from his wife.... I've had these discussions and people feel uncomfortable. No, say what you think.

-Sheri

Sensationalized trials such as the O.J. Simpson case only added to respondents' perceptions that money could buy justice. One of the final questions respondents were asked was what, if anything, they would change about courts, and almost half of the respondents said that they would change the degree to which money influences outcomes:

All is free and equal. That we all get our fair share of justice. Not more for some than others. It should be equal for everyone. No matter how much money your parents have. If rich kids do something, they should be penalized. Not daddy go get his lawyer and bail him out. No.

-Clarence

The buying of justice or supposed justice. The buying of getting off, getting your way. Keep it equal. I mean, um, I don't know if you saw the O.J. Simpson first trial. He had a battery of lawyers. He had a DNA lawyer, a blood lawyer, he had his own private lawyer, he had Johnnie Cochran, and two or three other lawyers. And they all had their own, um, niche. Thing that they did, and it was, at a point, it was bordering the ridiculous, where there were two prosecutors, and this battery of lawyers who you knew were actually going to batter these lawyers.

-Crystal

\section{Past Experiences with Courts and Other Institutions}

Even with a perception that money matters in the justice system, it is still not clear why respondents were so hesitant to pursue civil justice in cases where they would seemingly have little to lose. For example, if Tonya, the respondent discussed in the beginning of this Article who was being kicked out of her apartment by her landlord, had sought out free help from a lawyer, 
the worst case scenario would have been exactly where she ended up without the help of a lawyer: having to move out of her apartment.

In many civil justice instances, respondents appeared to have little to lose and potentially a lot to gain by seeking out the help of a free legal services lawyer. Certainly the time it takes to contact a lawyer and having to meet with a lawyer during work hours would be difficult for some respondents, but the consequences of the civil legal problem would, in many cases, be even more difficult and potentially time-intensive. When probed further about resistance to seeking out help, it became clear that for many respondents the decision to stay away from courts was more complicated than just the perception of a system in which money controls outcomes.

Weighing on these respondents were their past (and current) interactions with other public institutions. These experiences were some of the most difficult in their lives and made them feel ashamed, inadequate, degraded, and confused. Thus, any situation (including civil legal problems) that even remotely looked like it had the potential to invoke such feelings was avoided. The past interactions that weighed so heavily on respondents were often public benefit hearings that were not actually criminal in nature, but felt criminal and punitive. Indeed, some respondents thought that public benefit hearings were in fact experiences with the criminal justice system.

These experiences, often with regard to public housing, Supplemental Security Income ("SSI") benefits, ${ }^{14}$ schools, unemployment insurance, or welfare-the list went on and on-contributed to respondents' feelings that the "law" centered around criminal law. Most of the hearings they experienced on these issues focused on whether a benefit would be taken away based on something they had done wrong, for example, not reporting income while receiving welfare or a child being expelled from a school. It was not always clear during the interviews whether a respondent was describing an actual criminal case in court or some kind of non-criminal hearing, because the words used to describe the experiences were so similar.

One respondent, Larissa, explained that she had never been in a court, but she had an experience when she was on welfare that felt close enough. She was not clear on all of the details, but she said she was accused of having a man live with her. If found "guilty," she was going to have to pay back welfare money and lose all of her benefits. She had to attend a hearing on the matter, and her experience at the hearing led to a strong desire to avoid interactions with public institutions in general, especially anything that looked like a court:

They tried taking, f-ing me up that day. I had no idea, my foot from my hand from my mouth. I think I had a panic attack. I tried saying

148. SSI is a government program that provides stipends to low income people who are either elderly, disabled, or blind. See SOC. SECURITY ADMIN., Understanding Supplemental Security Income (SSI) Overview-2015 Edition, https://www.socialsecurity.gov/ssi/text-over-ussi.htm (last visited Mar. 8, 2016). 
what I needed to say, but no one was listening. That was a low, a low low low. I hated it all, that welfare. Always in my business. No siree, no thank you. ... Stay away from them courts and that kind of thing, let me tell you. That's a one-way ticket to feeling like crap.

Many respondents reported they felt a similar loss of control and dignity, and several of them described these experiences as low points in their lives. Candy, a mother of four, described a welfare hearing (she called it a court appearance) in which she thinks she was "charged" with misrepresenting her income and was eventually made to pay back past welfare earnings. She said:

You know, after that time in court with welfare, and then another time too actually, keep me away. Uh huh. Worst day of my life. They were wrong. I'll tell you that. I had all this documentation and papers and things with me, and no one cared. That guy, he used words I didn't even understand. And I remember he asked me a question, but I couldn't even tell he was speaking to me so I didn't answer. And then he got angry. The nerve. Worst day of my life. Remind me never to do that again, no way, no way. Keep me away .... You know since I really haven't needed help. I've made it on my own, and I can avoid things like that. I can and I have, you see how it is? It's not fun. Not fun at all.

I asked Candy whether she was in court or had to go to an administrative hearing, but she said she was not sure:

Hmm, you know, I don't exactly know. All I know is there was a mean guy asking me questions, and they didn't even let me finish. I think he was a judge. Uh huh, I'm pretty sure he was a judge. He wasn't wearing those black robes though, but he seemed like a judge, so I think it was a court for criminals.

The words "scary," "confusing," and "afraid" were used consistently when respondents described their experiences with administrative hearings or meetings to determine eligibility or other issues:

I walked in there and man, I was scared. It was all formal and I felt like my life, my earnings, were on the line. They were not nice. Not nice at all, in fact. I honestly found it very confusing.

-Tonya

Not many things make me afraid, but that sure did. I remember taking the train over there, and my stomach hurt. Had no idea what to expect. I knew it would be bad. And it was. Confusing right from the get go about where to go, and only got worse. I had to wait, wait, wait, and then it was over in a jiffy. No chance to even talk. Wouldn't want to do that again. 
I was scared, real scared. I didn't know how to act, what to say. I tried to look real sweet, actually.

\section{-Alberta}

Fear. Honest to goodness fear. That's how I felt. Fear of what would happen. What they would say. They were tearing apart my life and I wasn't even allowed to talk. To defend myself. Honey, let me tell you, it was no fun. Keep me away from all of that. Keep me away.

$$
\text { -Mya }
$$

One respondent Lily, described a meeting she had with the principal and several teachers at her son's school as a turning point in her perception of government institutions:

I felt helpless for me and for my son. Like I was on the witness stand and it wasn't even me in trouble. I knew they were out to get us even before I got there, and sure enough, that's how they acted. They can have it, they can take it. I want him out of that school, first chance I get and he will be. I know why my son acts out, if they make him feel like shit like they made me feel like shit with their snotty ways. You know, I think that's just how it is. It's just how it is with these kinds of things. The government, well, the government it is better to stay away from. I'm looking into programs to help him get help, money help, going to private school.

The experiences of the respondents in this study and their feelings about public institutions are consistent with the work of Lipsky, who notes that people who are unable to purchase services in the private sector must seek them from the government, and thus poor people often end up having significant interactions with street-level bureaucrats through a range of services and experiences. ${ }^{149}$ Further, " $[t]$ he experience of seeking service through people-processing bureaucracies is perceived by enough people as dehumanizing that the phrase 'human services' is often understood as ironic by all but those who work under that label." ${ }^{\circ}$ For respondents in this study, inaction was far more appealing than subjecting themselves to the feelings of dehumanization they had experienced in the past when dealing with streetlevel bureaucracy.

Some respondents described actual court experiences and feeling lost because they could not follow what was happening. They felt like outsiders attempting to navigate a new, complex world. There were a different set of norms and a new language in this world, and no one was there to explain it to them:

149. See Michael. LipSky, Street-LeVel Bureaucracy: Dilemmas of the Individual in Public SERVICES 1 1-12 (1980).

$15^{\circ}$. Id. at 27. 
It's so confusing! I didn't know who my lawyer was and I couldn't understand nothing he was saying. I couldn't even hear the judge. The case was over and I didn't even get to say anything-I don't know why to this day! It's messed up.

-Chris

It's weird because it's way different than TV. You know I'm a Law and Order freak. But it's weird. It's not the same.... [Interviewer question: What are the differences?] ... In the real court, I really didn't understand what they were saying. You know when they are talking, I don't know who is the lawyer, who is the defense. And the judge is way back there, you know? Just going in there everyone is sitting back there waiting to be called. It was chaotic but it also seemed scary.

Whether respondents had experiences with actual court hearings or public benefit hearings, the feelings they described were the sameconfusion, fear, and shame. All of these experiences were lumped together as experiences with the law, and they were negative experiences for most of the respondents. So negative, in fact, that they did everything they could to avoid experiencing such feelings again. This included avoiding any and all interactions with "the law," no matter how different their present situation and their past experience might appear to be to an outsider.

4. “I've Made It on My Own. I Don't Need No Lawyers or Courts": SelfSufficiency Narratives

As discussed above, for many respondents in this study, past experiences with public institutions were essentially the same as experiences with courts, particularly criminal courts. In fact, many respondents believed they had experienced a criminal justice court when most likely, from their description, what they experienced was a public benefits hearing. In general, respondents grouped courts and lawyers with other public institutions, and involvement with such institutions signaled failure. It meant asking for help, something they had had to do at vulnerable times in their lives and hoped they could avoid. Involvement with such institutions also signaled that they were in trouble or in need-a situation they actively sought to avoid. Respondents were quick to relate asking for public benefits help with asking for help with their legal problems:

I hated going and filling out all that paperwork for disability. I really needed it, I could hardly get up, my back was that shot. I got it, but they made me feel dumb. I resoluted there and then I'd get back on me feet. And I did. I do things for myself. . . . So if my neighbors stole 
something from me, I would handle the situation. I would look them in the eye and let them know I knew, and my look would tell it all.

-George

I haven't needed much assistance in years, actually. Actually, I like to do things myself, solve my own problems. It works out better and I feel better. It makes me better. No going back to those days. Unneeded. So yes, I would solve the problem myself. That's how I roll. In fact, that's what I did when I had a problem with my landlord, years ago.

-Cece

Cece equated seeking out a lawyer with getting "assistance" and said she did not want to go back to those days. Cece's quote shows a narrative shared by the majority of respondents: she solves problems herself and she does not want to ask for help. When she does have to ask for help, it means negativity and shame, and she fights against such experiences. Another respondent, Terry, described a similar narrative and resistance to going back to the "dark days":

Dark days. Welfare is dark days. I'm a worker now and I take care of myself. That's my MOA, my MOA. I take care of myself and I try to do this in all circumstances. I learned my lesson about how that feels. Someone always in your business. So I say, you have a problem, you take care of it yourself however you have to. That's my MOA. I would only seek out a lawyer if I was in real trouble, you know, my life was in danger, that kind of thing. It's against my MOA.

Being able to avoid lawyers and courts was consistent with a narrative of staying out of trouble, and people who are involved with the justice system are "people who go wrong." Antonia articulated this common sentiment when she said:

Well, the lawyers themselves aren't the reason not to go talk to them. I mean they suck, but if you are charged with murder one, they are better than nothing. If I really needed a lawyer, I'd go talk to them. I just don't need a lawyer never, really. I stay out of trouble and stay my own path. Who needs lawyers? People who go wrong. That's not me. I've had my share of needing help and it sucked. I'm done with that. So if someone do you wrong, there are two ways to deal with it. One is needing help and one is not. You take care of yourself. I take care of myself.

Tanisha, a young mother of four, first spoke passionately about the injustices associated with "poor persons' lawyers." However, when she was asked whether she would have pursued a civil justice issue she had previously described if she could afford an expensive lawyer, her response was: 
No, no. I must say I really just am a self-solver. I don't seek out others to solve my problems for me. I solve them myself. When other people get involved, it's bad news. Do it myself or don't do it at all, that's what I've learned over the years. That's my wisdom, honey, my wisdom at play. . . . Let the rich have them lawyers.

Tanisha's response raises another narrative that was shared by many respondents: they justified not seeking "help" with problems through a narrative of self-sufficiency. They also created moral boundaries between themselves and "the rich" who, they believe, overuse lawyers. Indeed, many respondents echoed Tanisha, remarking that they were not interested in lawyers, even privately paid lawyers, and that "rich" people are too quick to seek out help from lawyers:

Eh, I think those rich people overuse lawyers anyway. I solve my own problems. Me, me, me. I don't need no help. I'd rather do it myself.

-Malcolm

Some people are sue-happy. I'm not.

-Gary

[Rich people] can take their expensive lawyers and stuff it. My

Mama taught me how to do things for myself.

-Velma

I think there are some people in America, I'm just saying, who have too much time on their hands. And too much money. And so they go and they hire these people to take care of every last problem of theirs. Every last problem. That's not me. I would only do it if I really needed it, even if I was a millionaire. Put your money to something good. Don't give it to lawyers. You know? That's just me though.

-Rick

Notably, all of the respondents in this study were living in public housing, so they were indeed receiving government assistance. Many of them were receiving assistance from various government benefit programs, including the Supplemental Nutrition Assistance Program ("SNAP"), commonly referred to as food stamps, disability payments from SSI, and Temporary Assistance for Needy Families ("TANF"), commonly referred to as welfare. When asked follow-up questions that sought to determine how these forms of assistance fit into their self-sufficiency narratives, respondents often acknowledged such assistance but noted ways that they had moved beyond other forms of assistance (often TANF) they had previously received. Respondents made it clear that the goal was to need less help, not more, and that seeking legal assistance meant moving in the wrong direction:

Yeah, I do in fact get food stamps and housing assistance. You know my rent is very low. But let me tell you, I was in a homeless shelter. . . . 
[N] ow that was bad. I'm making it on my own. Those programs help but I'm making it on my own and I'm going to make it on my own. I work for what I got and work to move on. Keep on moving on and up.

-Tia

I have some programs in place, but I'm done. Signed, sealed, and delivered. The last thing I need is more government in my life. More lawyers, more paperwork, more trouble. I stay in my own business, and let others stay in theirs.

-Betty

The help of a lawyer signaled a failure in self-sufficiency as well as entrance into an institution that could, and in many cases had already, invoked feelings of inadequacy. For these respondents, increasing the availability of legal services lawyers would do little to help them resolve their civil justice issues. The ability to avoid seeking help and the potential shame and fear that may come with it usually trumped the far-off seeming ability to have the civil justice issue resolved in a favorable way.

\section{B. RACIAL DIFFERENCES IN CTVIL JUSTICE PERCEPTIONS AND UTILIZATION}

For the most part, ${ }^{15^{1}}$ black and white respondents had similar perceptions of the justice system and similar explanations for their use or avoidance of formal law when faced with civil justice issues. However, when it came to trust and corruption, the views of black and white respondents diverged. The differences in levels of trust played a key role in black respondents' conceptions of themselves as self-sufficient citizens, and in turn, their resistance to seeking help when they experienced a civil legal problem. This Subpart will discuss the results of this study as they relate to trust.

\section{Race, Trust, and Use of Civil Courts}

There were clear racial differences between respondent groups when asked about trust of courts. Out of the $5^{2}$ white respondents, 39 respondents $(75 \%)$ said they ultimately trusted courts. One respondent, Tara, said: "Well, you gotta trust them. They are courts of law. They go back to Abraham Lincoln, George Washington, all that. There's a lot riding on them. Where would we be without them?"

Some white respondents said that they did trust courts, but added qualifications to their statements. For example, one respondent, Mary, said, "Well, they're not always fair, but in the end I trust them. They do a good job, as good as they can." Another white respondent, Vicky, echoed this sentiment,

151. As this Part will discuss further, trust levels were a key difference between black and white respondents. 
"Yes, they are not perfect, but I do trust them. What is not to trust?" Similarly, a white respondent Bryan said: "Yeah, I trust them overall. There are mistakes that are going to be made, but in the long run $I$ have a feeling that the way that it is set up is as fair as it possibly can be. Except with O.J. Simpson." Another respondent, Alix, had a slightly different take. She stated that overall she trusted courts, but "I don't trust them for people with money. Sometimes it works. Sometimes the system works but then sometimes they buy their freedom."

The white respondents who said that they did not trust courts tended to focus on specific experiences in the court system-either their own or those of family or friends. For example, one respondent Candy said: "No. I don't know. I don't trust the legal system. I've seen my friends go through a lot of stuff and get smoked for no reason." Another white respondent, Elliot, who had been in front of a judge himself several years prior said: "Hells no. Excuse my language, but no. I saw how things operate there. Complete chaos. Awful. No one knows anything. Definitely don't trust it. I'd do a better job than anyone there."

In contrast to the primary ethos of trust in courts among white respondents, only ten of the 45 black respondents, or $22 \%$, that I interviewed said that they trusted courts. ${ }^{152}$ Not only did far fewer blacks than whites say they trusted courts, but black respondents also responded to the question with a different overall thought process about trust from most of the white respondents.

Most white respondents focused specifically on courts, talking about why they ultimately did or did not trust courts, often drawing on past experiences or things that they had heard. Most black respondents, however, focused on trust as a broader topic. In response to the direction question: "Do you trust courts?", one black male respondent, Chuck, said: "You can't trust nobody or nothing today. You don't know who will do what to you." Another black respondent, Michelle, said: "I don't trust anybody. I trust me and that's it." A third black respondent, Taylor, put it bluntly:

You can ask me if I trust courts, the police-damn, ask me if I trust my husband. The answer will be the same. No, no, no. I've gotten burned too many times by too many people. I'm very careful. My guard is up all day, every day. I am careful.

Several of the black respondents, such as Elsa, were straightforward about the roots of their distrust:

152. For an interesting discussion of within-race socioeconomic differences of blacks and their trust levels and views of the police, courts, and other legal institutions suggesting that higher income blacks may be less trustworthy and believe courts are less fair than lower income blacks, see Brooks, supra note 78; and Richard R.W. Brooks \& Haekyung Jeon-Slaughter, Race, Income, and Perceptions of the U.S. Court System, 19 BEHAV. SCI. L. 249 (2001). 
My mother was a strong woman, and she taught us from the start that the only person or thing we could trust is ourselves. She'd tell us to be careful. We weren't allowed to say hi and goodbye to people we didn't know. She didn't let us do a lot of stuff with groups if she didn't know who ran the group. She instilled a lot of that in us.

Another black woman, Krysta, also describing how her mother taught her to only trust herself, noted:

Even when we were at people's homes who we knew, we had to sit there and be quiet and not ask for nothing like food or drink because my mother said you never know what they put in there. Be careful, be careful, be careful, that's what she always said.

When black respondents talked about their childhood and what their parents taught them, most of them noted, with pride, that their parents taught them how to be "careful." White respondents gave more varied responses, but memories such as one from Carl, a 62-year-old white male respondent, were not uncommon:

I grew up in an Irish neighborhood. ... Did I trust the people? Of course, I had to. They knew who I was. Everybody knew us. For the first 25 years of my life, I don't think a door was locked. In the doorway I lived in, in Washington Elm, it was all families. I could tell you the names of the families to this day. If my mother wasn't home, one of the ladies on the second floor would come and check on us. She didn't do it because she was asked, she just did it.

Other white respondents talked about an overall philosophy encouraging trust, but noted, like Eileen, that "[my parents] did say to be wary of strangers and not take candy from them-you know, the normal stuff."

The contrast in answers between black and white respondents when asked about trust in courts held in answers about other institutions as well. Before asking about courts, I also asked respondents if they trusted the police and if they trusted their neighbors. For the most part, black respondents' answers to these questions were similar to their responses about courts. They invoked invoked broad answers about trust in general, stating, for example: "I only trust myself." Natasha's answer to the question about whether she trusted her neighbors was typical:

Ha! Sweetie you don't trust your neighbors. You just don't. Hell, I don't trust everyone in my family. Why would I trust my neighbors? There are Godly neighbors, sure, and in the words of God I respect my neighbors because He tells me to. But trust them. Nah. I know to watch out. Watch my back.

White respondents mostly focused on the institution in question, and answered by drawing on past experiences with the same institution or group. Trust, for most white respondents, was something specific to individual 
people, organizations, and institutions, and for the most part they did not have a general policy about trust in the way that many black respondents did. For example, when Colin, a white respondent, was asked whether he trusted his neighbors, he said:

It depends, of course. Some are good people, some are not. Now [my neighbors], they are good people. I've asked them to help me out a few times. When my car broke down, [my neighbor] even gave me a ride to work. Good people. That couple who moved in next door. They are shady. I'm guessing drugs. People in and out of their apartment at all hours. I don't look them in the eye. Don't want to get involved.

When respondents were asked whether they trusted the police, their responses similarly varied by race. Most of the black respondents answered with the blanket statement that they did not trust the police-often in the context of advice (to the interviewer) that it is best not to trust anyone. Chantell said:

Honey, you are young. Let me give you some advice. It's advice I was given when I was young, and it's good advice. Don't you think that just because the police are authority, that they have power that you should trust them. It's the opposite. You keep your guard up. You don't look at them, you turn the other way, but don't be obvious. You are white, I'm black, but it still holds. Even the black police are no good. People with power are on a power trip. People make the mistake of thinking those with power you can make an exception, that they are trustworthy. But they are not. In fact, they are worse than those without power. They are shady.

Another black respondent, Charise, connected the police, courts, and neighbors. After she was asked about trusting all three, she noted:

You can keep asking, and keep asking. But I'm not gonna tell you I trust no one or nothing. I don't. I trust me, I trust my Mom. I trust my sister. That's it, uh huh, that's it. Not even my other sister. Other people, they are out to screw you. You keep your guard up. I'm in fact showing my kids that now. I don't even let them go out for Halloween. You never know. So I buy them some candy the next day when it's on sale. Safer. And they can get what they want.

\section{Racism}

Concerns about racism certainly contributed to black respondents' mistrust of the legal system and other institutions. However, it was difficult to calculate exact percentages of black and white respondents who had concerns 
about racism in the justice system. Respondents of both races gave nuanced responses specific to individual situations. ${ }^{153}$

Many black respondents who said that they believed racism is a problem in the court system noted that it really depended on the individual judge and the individual jury. As one black respondent, Rhonda, said:

It's mostly men in court. They are mostly older and they are mostly white men. So when they grew up, [racism] was okay. But the judge my kids had was a biack woman. And she fought for them. Everything I was trying to tell them, she told them. She was a single mom, and she had two sons at home.

Daisy had a similar sentiment:

There is indeed racism in courts-and everywhere-because there are racist people. But judges, juries, no more than anyone else. Sometimes I'll get a black judge this time. A Spanish judge the next time. The jury may be black. Or I may get a white peace keeper. So yes, there is racism, like anywhere else, but not always.

Another black respondent, Mia, stressed that she thought that unfairness in court outcomes was caused by access to money and power more than by race, a sentiment many other black and white respondents shared:

I think that who has power or not changes things. People who don't have access to power get brought to court. People who have really good lawyers, it helps them. I mean it's also acts of power. I think access to power matters a lot. And I don't think about it in terms of race, but access to power. But it's connected.

For some black respondents, the O.J. Simpson murder case was front and center to their belief that money, more than race, was a significant factor in court outcomes. Several respondents noted that they had watched hours upon hours of the Simpson trial and had concluded that he was guilty. This case, they said, was striking to them and the root of many of their beliefs about courts and fairness. Ella, a black respondent, said:

For a very long time I thought racism explained it. Explained it all with police and courts and all that jazz. But look at O.J. He got away with murder and look at the color of his skin. Black, black, black. And the lady was even white. But I'll tell you what he does have. Money. So, yes, race matters, but money matters more. Money can make race, black skin, go away. What do you do with that? I'm not even sure.

153. It is important to note that in the criminal court context, studies have documented that blacks are indeed more likely to receive biased treatment than whites. See generally COLE, supra note 89; WESTERN, supra note 17. Additionally, there is documented historical racism in the judicial system. See generally KENNEDY, supra note 18 . 
There were certainly other black respondents who believed racism was a significant problem in courts, and a reason to avoid the legal system. As one respondent, Thomas, said:

There is racism because it's the government. The government is racist, and courts are government. Same with the police. I know I won't get a fair chance because of the color of my skin. You hear about it all the time. All white juries stacking it against blacks. It's there. It's definitely there.

Another black respondent, Walter, in response to what he would like to change about courts, said:

The fact is that us blacks are never going to have it fair. Because of the color of our skin. For us jail, for other not. That is not fair, not fair.

The answers of white respondents were similarly mixed when considering racism in courts. One respondent, Colleen, summed up the beliefs of most of the respondents:

So, in fact, I am sure there is racism, just like there is classism, and sexism, gayism.... There are laws that are supposed to make things fair, but sometimes those laws don't work in terms of people. It's all about people, as you know.

Similarly, Mary, also a white respondent, said:

Of course there is racism. If you think we've moved beyond that. You have your head, well it's not screwed on straight. You'll find it with some people, not others. It's not just courts. I, for one, don't have a racist bone in my body. But some people do. It's always a concern.

Both black respondents and white respondents believed that there is some degree of racism in courts. However, unlike their responses about trust, black respondents were more nuanced when answering questions about racism. They noted that there was a chance they could end up with a black judge, for example. As one respondent, Tia, said: "It is sort of racism, but it goes deeper. Even if the judge is black, the jury is black, there is still a problem. Don't trust anything or anyone." Concerns about racism certainly factored into their decision not to seek out formal legal help, but just as Sandra Smith found in her study of blacks and employment, many black respondents do not trust other black people. ${ }^{154}$ A generalized lack of trust, even more than concerns about racism, seemed front and center to their decision to try to ignore civil justice problems.

154. See supra notes $112-18$ and accompanying text. 


\section{Race, Corruption, and Use of Courts}

Consistent with their distrust of courts, black respondents were more likely than white respondents to believe that there is widespread corruption in court proceedings. Just over half of the black respondents talked about their suspicion that courts are corrupt, whereas only six white respondents expressed a similar sentiment.

Both black and white respondents believed that money could "buy" justice. However, for many respondents, the idea that money could buy justice focused on whether one could afford a high quality lawyer-one that could give a case adequate time and preparation-instead of a public defender, described by most respondents as "bad" lawyers without enough time or concern for cases. The focus on the sentiment that money could "buy" justice was on the lawyers and their ability (or lack thereof) to effectively argue a case.

The idea of corruption, however, was more extreme. The respondents who talked about corruption believed that money was being used to "buy off" various parties (lawyers, judges, and juries), or that the system was specifically and purposefully rigged against certain people (in most cases, poor people were discussed, in a few cases, racial minorities). As one black woman respondent, Charise, said:

I don't like crack, I don't like heroin. They do damage to yourself and family. The courts, they are the problem. These aren't the people who brought in the drugs. Go after the big people. But the courts, then again you have to keep the drugs because that is big money, that is big business. Keep drugs, it keeps feeding the bigger people. So that's what the judges do. They want money, so they just keep the drugs in for the big rich guys who pay them off.

Another black respondent, Wilmer, was similarly suspicious of judges:

Never trust a judge. They are human, like everybody else. If they are not getting anything from it. If they are not getting a pay raise they would take money. You may think this is silly but it is true.

When asked an open-ended question about one thing they would change about the legal system if they could, some black respondents focused their answers on changing corruption within the courts:

You know what, I never thought, I think there should be more cameras in the courtroom. [Interviewer: Tell me more about that.] Because I'm watching everyone. I don't know if you paid off a juror. I'm watching the expressions. Who is looking at who? I want the cameras watching everything. There is a lot going on. Who is paying who? Who is paying this juror? You know you may see a lot of TV is about courtrooms and who paid this and this. And it's fiction. But there is a basis of truth. I want cameras watching everything. Who is 
making deals? Who is up for election? Who is this client? Who is going to benefit? And a camera tells a lot.

-Betty

Independent monitors. People there to monitor judges and juries and lawyers. There is a false sense that what goes on is fair, and just. But in fact, it's the opposite. They are trying people for doing something wrong, but I'm telling you those monitors would find something in every single case. The judge sleeping with this juror, or that juror. The lawyers in bed together. You never know, but it's severe. There is inbreeding. And how those jurors get picked. I'm telling you it's no mistake. It's no chance. I was informed I had to go to court once to be considered for a jury. I sat there the whole damned day, then I was told I wasn't needed. It's not a coincidence. I didn't have anyone to be in bed with, so I wasn't needed. Ha. It's a joke. So independent monitors, that would be a good change. A good one.

-Hilda

Many black respondents discussed the O.J. Simpson murder trial in the context of corruption:

I think [O.J.] killed his wife and that man. If he didn't get off, a lot of blacks would have been upset and it might have caused a race riot. So they stopped that from happening. They probably paid off the jurors... [Interviewer: Who paid off the jurors?] ... The government. The judge, maybe? Who knows.

Take the O.J. case. Now that was a conspiracy if I've ever seen one... [Interviewer: Tell me more about that.] Well, I'm just saying. Something happened there. I watched every minute I could of that trial. Riveting. And guilty as hell. Something happened. Only God knows why, but it was a conspiracy. I can tell you that much. I feel for that lady Nicole and her poor children.

-Lauren

A few white respondents believed that there was widespread corruption in courts, but most did not bring up corruption unless prompted. When asked about corruption towards the end of the interview, Melanie's response was typical of white respondents:

Nah, not really corruption. That's things you see on TV, like madefor-TV movies. Money can get you places, but it's more about time than anything else. The lawyer having time for you, giving you the time of day. I've definitely seen movies about that, though. 
Michael, a white man, said it can occasionally happen, but it is more the exception than the rule:

I mean judges are men of the law. Oh, and women too. I don't think there is actual corruption or shady stuff going on. It's unintentional but there. It's about having the money to buy a good lawyer. A really good one like those celebs get. But even public defenders, it's not that they are corrupt-they are not, well, not the brightest. I think a lightbulb is missing for a lot of them. That's why they went into this line of work. They are good people, just not, just not who you want to put your life on the line with because they are not all there, their minds.

These fundamental differences in perception of trust and of corruption can lead to different behaviors when poor blacks and whites are faced with civil justice issues.

\section{Civil Justice Utilization Differences: Black and White Respondents}

The most striking difference between black and white respondents was the degree to which they trusted courts. These differing trust levels led to differing behavior when respondents were faced with civil justice issues. Both black and white respondents were resistant to seeking out help from the formal legal system, as discussed above. This Article's findings indicate, however, that whites were more open than blacks to seeking out help in some specific circumstances, particularly when self-help measures failed and the consequences of ignoring a problem were significant. Indeed, we know from existing survey data that when poor people were experiencing a civil justice problem, $29 \%$ did, in fact, turn to the formal legal system for help. ${ }^{155}$ This percentage is low, but still significant. While there has not been a study that has broken this data down by race, this Article's study suggests it is likely that the $29 \%$ of poor survey respondents who sought out legal help were disproportionately white.

Because my sample did not contain a group of people who had all experienced a similar civil legal issue, I asked a series of hypothetical questions: asking respondents to imagine themselves experiencing various civil justice problems and asking what (if anything) they would do first, second, and so on, to deal with the issue. It is important to acknowledge the disadvantage of hypothetical questions: respondents had not actually experienced the situation, so how they predict they would act may not be how they would actually act. However, as one of many tools in the interviews, hypothetical questions allowed me to look for patterns in responses of action or inaction to the same potential legal problem.

155. Consortium On Legal ServS. \& THE PUB., supra note 3 , at 11. 
When I outlined the civil issue the respondent should imagine him or herself experiencing, I did not ask the respondent if he or she would go to court to solve the problem, but instead laid out the scenario and then asked, generally, "what would you do?"

One scenario was the following. The respondent was renting an apartment and in the middle of winter the heat stopped working. The respondent had contacted the landlord several times over a period of about two weeks, but the landlord ignored many of his or her calls and once mentioned that space heaters work well. During this two-week period, Boston was having a cold spell and the temperature was below freezing.

Almost all of the respondents, both black and white, said that they would initially invoke self-help to try to solve the problem. One white female respondent, Mary, said:

No heat and a child? I'd take care of it on my own. I have resources and smarts to do that; I don't think I would need to seek legal help. First I would call an oil delivery man. Tell him my case, and if he said there was nothing he could do, the delivery man, then I'd ask 1-80oASK-JOE. That is free oil. [Interviewer asks what she would do if it was not a lack of oil problem, but rather a broken heating system problem.] If the heat was actually broken, I'd call someone to fix it, and I'd tell them we needed it fixed, and so I can't pay you, you're going to have to go to the landlord. And I would tell him if you need help collecting from the landlord, I'll help you.

Similarly, Gloria, a black respondent, said:

I would not want to bother with rocking the boat, it's just not how I operate. I would try to reason with him more. You know, make him feel bad for me to get to his core. I'm very persuasive, myself. And I'd let him know it's his responsibility. His job.

Mary, the white respondent, qualified her statement by saying,

If [the self-help remedies] didn't work, I would pay for it. I'd pay for it in installments and say I want receipts and then I would take the owner to court and I would sue him. I hate that idea, really I do, but sometimes you have to do what you have to do.

Gloria, however, had a very different course of action in mind if her selfhelp remedy did not work:

So I'll withhold my rent, try to find another place, take all my belongings and move out [instead of going to court]. And he can have his apartment. I deal with things myself. It is just how I was raised. My mother taught it. Take care of what you need to. It's a strong background.

Out of the $4^{6}$ black respondents I interviewed, only four suggested that they might bring the landlord to court. Instead, the majority of black respondents 
said they would ultimately move out of the apartment if they could not convince the landlord to fix the heat; fix it themselves, as some who were handy suggested they would try; or use space heaters and "'rack up a big ole' electric bill I couldn't pay, but I would somehow find a way to deal with." Al, one of the black male respondents I interviewed, put it this way:

I would move out. I won't tell ya what I might do to the guy though. Or what my friends might do. I'm kidding. I'm kidding. But I'm not going to no court, no way. Might as well ask for a rights violation, the way those courts are.

Another black respondent, Harris, when talking about the possibility of going to court over a complex employment issue he had experienced said, "Why would I waste my time in court? You never know who is paying off who. I'll just take care of it myself. Why risk it?" The theme of "risk" was present in almost half of all black respondent interviews when they talked about the possibility of going to court to resolve an issue. The theme of risk was often combined with the self-sufficiency narrative that many respondents also invoked to explain not wanting to seek formal legal help. When the interviewer followed up with Harris, asking "tell me more about the risk of going to court," Harris said:

You can't trust it will be what you put in for. I may go in to sue my boss and come out in jail. They'll find something to hold against me, to get me for. Lots of behind the scenes stuff going on, my boss might pay someone off, might be friends with the judge. You can't be too careful. Better to handle things yourself, anyway. My boss is a powerful man. You can end up screwed, and I mean royally screwed, not just losing your case. My case will turn into something else, that I guarantee.

Misty, a black woman, felt similar to Harris, as did many other black respondents. When talking about her decision to simply ignore a pressing civil justice problem, in her case a housing issue, Misty said, "It's too big a risk making contact with the law. You never know what will happen, and you can't trust it. I am someone who handles things myself. I don't need the help, and I don't want to risk the help."

This finding regarding risk is consistent with Sandra's Smith finding of "defensive individualism" among black jobseekers when it came to asking for help when finding a job. ${ }^{15^{6}}$ The findings in this Article suggest that this defensive individualism may be more pervasive and affect other aspects of help-seeking behaviors outside of the employment context. The generalized distrust black respondents talked about when justifying their lack of action when it comes to civil justice problems may stem partly from defensive

156. See supra note 117 and accompanying text. 
individualism. In the same way jobseekers were reluctant to seek help because of a fear of how they were viewed by others, and thus used individualism as a means of justifying this reluctance to seek help, black respondents in this study may have been concerned with how lawyers and other officials viewed the problems they had. Thus, a generalized identity of distrust and individualism may have been, in part, a way to avoid judgment and potential embarrassment when seeking help.

The white respondents in this study were more mixed than the black respondents about the potential to bring an issue to court. Out of the 52 white respondents I interviewed, when posed with the hypothetical question about the landlord who would not fix the heat, $21(40 \%)$ said they would at least consider seeking legal advice or trying to bring the landlord to court. Only four of the 21 who said they would consider seeking legal advice said that they would immediately seek the advice of a lawyer. The remaining 17, like Mary (above), said they would only seek formal legal help after self-help measures failed. As Christine, another white respondent, put it:

With all my heart and all my soul I would avoid law. I always do with every problem I have. I am a selfer, a selfer with problems. But if it were freezing and I couldn't afford to move, I might have to call and find out what my options were. My legal options. I did something like this once before when I wasn't getting my disability check for weeks on end. I do have rights and if I have to, I go after them.

The percentages of each racial group that said they would seek formal legal help in the hypothetical landlord situation-nine percent of black respondents and $40 \%$ of white respondents-were consistent with the number of respondents who reported having sought legal advice in a (nonhypothetical) civil justice situation. Roughly $35 \%$ of white respondents had done so at some point in their lives, whereas only about ten percent of black respondents had ever sought out formal legal help (for a civil justice issue) ${ }^{157}$

An important question was: what differentiated respondents of either race who either had sought out, or said they were willing to seek, formal legal help from those who did not? The major difference between respondents in this Article's study, of both races, was whether they knew of, or had experienced, a positive example of the legal system. One black respondent, Aubrey, who had once sought out help from legal aid to potentially take action against a past landlord said:

Well see my sister, my sister had gone and gotten herself a lawyer when she was about to be evicted. Bless that lawyer's soul. She worked so hard for my sister. I think those legal aid lawyers, they

157. These statistics do not include people who were sued by another party and then sought the advice of a lawyer for their defense. My focus was on people taking action to address a civil legal problem they were experiencing. 
work hard for you, as long as you are a good person. My sister, she a good person. So am I. So I knew I would be taken care of. And I was.

A white respondent, Liz, who said she would consider seeking legal help if self-help did not work said:

[M] y friend Trish, she actually did see one of those Harvard student lawyers. They were real nice, apparently. The hospital put her in touch, believe it or not. And they worked things out for her, believe it or not. So maybe they would for me. I would try them first.

While respondents were not specifically asked if they had family members or friends with positive experiences with the justice system, all four of the black respondents who had previously sought out legal help noted in their interviews that they had had family members or friends who had told them about positive experiences with the justice system. Three of the respondents specifically said that those stories had contributed to their decision to seek out help in their own situation. Out of the 18 white respondents who had sought help from the legal system, 11 related positive experiences of family or friends as a contributing factor to seeking out help.

\section{AGENDA FOR FURTHER RESEARCH AND POLICY CONSIDERATIONS}

\section{A. AGENDA FOR FURTHER RESEARCH}

As discussed in Part III.B, this study provides important grounding for further representative studies of disparities in racial and socioeconomic civil justice utilization and experimental studies of potential policy interventions. Access-to-justice research is in its infant stages, but the need for more research is immense, and the potential for important follow-up studies to this one is significant.

First, more knowledge is needed about the types of problems that would most benefit from legal assistance, versus non-legal assistance, versus self-help, versus doing nothing. It is difficult to know how to allocate resources when the hard data about outcomes for the different types of potential help (or non-help) is non-existent. Long-term experimental and survey studies are needed to begin to dissect the complex web of problems and outcomes.

Additionally, more work is needed to better understand how structural differences (and potentially changes) in areas such as civil legal service delivery, policing, public defender offices, and courtrooms (at all levels), to name a few, affect perceptions and utilization of the justice system. There is potential that the renewed focus on, and potential changes to, criminal law, policing, and community trust ignited by the Ferguson movement will spur renewed trust in all aspects of the legal system, including the civil legal system.

Another important area for inquiry is the role of networks in legal service perceptions and utilization. As discussed in Part IV, findings from this study suggest that those who were positively inclined towards utilizing Legal Aid had 
either had a positive experience with legal services themselves, or had family members or friends who had related positive experiences. The sample was too small to make definite conclusions, but more work is needed to understand the decision-making process of those who do seek help from Legal Aid, and how those interactions either encourage or discourage further help-seeking behavior.

These are just a few of a plethora of important areas for further exploration. As the access-to-justice field grows and expands, I expect these questions and many others to begin to be addressed. Important first steps are emerging. For example, in May 2015, the DOJ's Office for Access to Justice and the National Institute of Justice, in collaboration with the National Science Foundation, hosted a Civil Legal Aid Research Workshop at the DOJ.158 The workshop brought together an Expert Working Group of approximately $4^{\circ}$ domestic and international researchers and practitioners. Over two days, the group, including myself, discussed the existing access-tocivil-justice literature as well as research gaps concerning civil legal aid. Attorney General Loretta Lynch spoke to the group and emphasized DOJ's commitment to access to justice work. Stemming from the workshop are significant funding and research initiatives that are sure to contribute to a better understanding of access-to-civil-justice needs in the United States. ${ }^{159}$

\section{B. POLICY CONSIDERATIONS}

As more knowledge is gathered, areas of potential policy intervention will become more salient. This Article provides a better understanding of the underlying mechanisms that contribute to low income individuals' inaction on civil justice issues, which in turn can help better design policies that might promote access for a wider range of those in need. While a complete policy agenda is beyond the scope of this Article, this Article offers policy hypotheses worthy of further consideration and study.

First, the findings suggest that innovative programs aimed at resolving civil justice issues outside of the formal legal system may be beneficial to poor and minority communities. Allocating additional funding for programs that provide aid for self-help measures, for example, may be just as important an investment in poor and minority communities as increased funding for legal aid offices. Programs that play to the strengths of these communities, in particular their desire for self-sufficiency and self-help, may be effective in allowing problems to resolve without cascading into larger problems with undesirable consequences.

158. U.S. DeP'T OF JuSTICE \& NAT'L SCI. Found., White House Legal Aid INTERagency ROUNDTABLE: CIVIL LEGAL AID RESEARCH WORKSHOP REPORT 3 (2016), https://www.ncjrs.gov/ pdffiles $1 /$ nij/249776.pdf.

159. Id. 
An important concern about such programs, however, is that self-help solutions might target the most capable of low income populations, and the neediest-those unable to read or those who do not have the tools to fill out paperwork and follow through-will be left without help. More research is needed on how self-help programs are used by and affect a range of potential "clients."

Current research is just beginning to shed light on specific civil justice problems for which a lawyer makes a difference in outcome and those that, at least based on early empirical study, may allow for similar or even better outcomes when self-help in legal proceedings is used instead of a lawyer. ${ }^{160}$ While much more knowledge is needed, a starting point for increasing the effectiveness of self-help strategies is to tackle the unnecessary complexity of many civil justice laws and procedures. There have been calls for reform in specific areas of civil law, but the procedure for change is slow and met with resistance. The DOJ's relatively new Office for Access to Justice may be a good catalyst for such a campaign, though in many cases changes would need to be made state by state, issue by issue.

Ultimately, increased resources for self-help may offer some benefit, but its utility and success would likely be limited to a certain subgroup of people with particular skills, and would also depend on the legal area of need. Focusing specifically on the group of people with whom this study is concerned-those who have a civil legal problem but do not seek help, I propose a new program that would provide legal help outside of the context of a law office. The program would be called the "Community Advice Corps," rather than Legal Aid. As the findings from this study suggest, the name "Legal Aid" may invoke strong negative feelings for some poor and minority individuals. For many respondents, anything "legal" was associated with the criminal justice system, and thus was suspect. The name Community Advice Corps would serve to "delegalize" and deformalize the help-seeking process in a way that would make it more comfortable for those who have negative perceptions about law in general due to experiences with the criminal justice system.

The Community Advice Corps program would take as a premise the findings from this study - that many of its potential clients group lawyers and the law in with other public institutions they did not trust and viewed as their

16o. See, e.g., D. James Greiner et al., The Limits of Unbundled Legal Assistance: A Randomized Study in a Massachusetts District Court and Prospects for the Future, 126 HARV. L. REV. 901 (2013) (comparing the results of clients offered traditional legal representation with those offered selfhelp resources); D. James Greiner \& Cassandra Wolos Pattanayak, Randomized Evaluation in Legal Assistance: What Difference Does Representation (Offer and Actual Use) Make?, 121 YALE L.J. 2118 (2012) (measuring the effect of an offer of, and the actual use of, representation); Jeffrey Selbin et al., Service Delivery, Resource Allocation, and Access to Justice: Greiner and Pattanayak and the Research Imperative, 122 YALE L.J. ONLINE 45 (2012) (arguing that empirical research should play a role in evaluating the delivery of legal services). 
adversaries. ${ }^{161}$ Thus, the goal would be to make lawyers and legal advice as approachable as possible and to house legal services in institutions that are otherwise approachable and non-adversarial. For example, community churches could offer times that lawyers would be available in recreation rooms for questions, advice, and potential referrals. Different strategies for increasing utilization could be tried-for example, holding the legal clinic directly after services, so that potential clients are already in the building.

Schools could be another potential home for the Community Advice Corps. While some respondents had negative experiences with schools, others viewed schools as one of the few public institutions that helped their family. Perhaps a model of "community schools," which was suggested as part of the "Human Renewal" programs of the 1960s in New Haven, Connecticut and other cities, could be reintroduced under different circumstances and with somewhat different ideals. ${ }^{162}$ The idea at the time was to increase the role of schools in the community and to make them not only places children received an education but also resource centers for parents. ${ }^{16_{3}}$

Using that model as an example, schools could host clinics meant to provide parents with legal and other social service advice, or they could have community rooms devoted, full time, to providing such services. Other community organizations and buildings, such as those that host Head Start and Job Corps programs, could be considered as well.

Whether hosted in churches, schools, or some other community organization, the idea of the Community Advice Corps would be to make the first step of seeking legal help less intimidating by embedding its availability in institutions that are perceived as trustworthy. Legal Aid offices could hire specific lawyers as members of the Community Advice Corps (moving them out of local field offices either full or part time), or a fellowship program could be developed for new lawyers-either privately or through the government. Independent of the exact details of the funding and staffing, the goal would be that people like Tonya, who did not even consider speaking with a lawyer, would feel comfortable seeking help.

\section{CONCLUSION}

This Article is the first to systematically study and document the confusion and connection between civil and criminal law among the poor. Indeed, it is not entirely surprising that the criminal justice system is at the forefront of the minds of the poor when they think about the law, courts, and lawyers. Why? Because existing data tells us that people in low socioeconomic groups have a much higher rate of interaction with the criminal justice system

161. See supra Part IV.A.3.

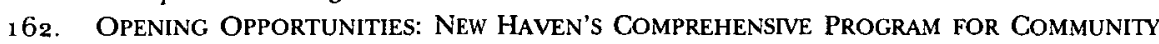
PROGRESS 12 (1962).

163. $I d$. 
compared to people of higher socioeconomic levels. ${ }^{16_{4}}$ Additionally, television tends to focus on the criminal justice system, whether through dramatic shows like Law and Order or around-the-clock coverage of real-life criminal trials. Criminal law not only dominates their lives, but it also dominates popular culture.

Negative experiences with, and perceptions of, criminal law, coupled with negative past experiences with public institutions, means that for many poor people, seeking formal legal help is off the table. In fact some poor people develop a moral narrative of self-sufficiency-not seeking help is the morally superior thing to do.

For this group of people, the focus on providing more funding for lawyers in Legal Aid organizations would only make a difference if the increased funding resulted in significant structural changes that gradually resulted in a cultural shift of understanding about how the law works for, and interacts with, poor and minority communities. Indeed, we can think about two different definitions of access: (1) structural barriers to access-focusing on funding, lawyer availability, number of Legal Aid offices and their locations; and (2) cultural and cognitive barriers to access-focusing on barriers to access stemming from life experiences that result in help not being sought in the first place. Existing advocacy and research focuses primarily on the structural barriers. I argue that we should be concerned with the cultural and cognitive barriers as well, and seek to better understand the connection between the two different, yet interrelated, set of barriers.

Why should we care? An important question is always resource allocation in a world of limited resources. If there is already a major shortage of lawyers for needy people who do seek help, why might we want to focus resources on those who do not seek help to begin with? Indeed, why should we even care about this group at all? For one, as we have seen all too clearly in the past year, citizens who feel disconnected from the State are angry and are demanding change. ${ }^{65}$ There are strong moral arguments for paying attention to the disconnect that many Americans feel between themselves and mainstream society. As the divide builds, so does the resentment and anger. One might also postulate that those who do not seek help are perhaps more needy than those who do-perhaps those who seek help but are turned away from Legal Aid have the internal drive and resources to seek other help. We need much more research, however, to know for sure.

But beyond moral arguments and concern about the growing race and class divides in America, there is perhaps another argument as well. While a formal cost-benefit analysis is beyond the scope of this Article, past research has shown that by not seeking legal help, at least in some instances, people can end up experiencing a cascade of problems stimulated by the initial legal

164. See WESTERN, supra note 17 , at $34-38$.

${ }_{165}$. See Capehart, supra note 30. 
problem. This downward spiral may, in fact, cost the government more money per person than providing help to tackle the catalyst of the downward spiral. Of course much more research is needed to determine the mechanics of how and if this happens, but I close with Tonya's complete story.

Recall that Tonya had two young children, was evicted by her landlord (for complaining about dangerous exposed electrical wires), and had only one-and-a-half weeks to move out of her apartment. Given the extremely short time frame, Tonya, who had been living in Cambridge, MA, moved in with her mother, who lived in Braintree, MA. Tonya explained, as she was relating this story, that the consequences of this move were more than she had ever imagined.

Her job stayed in Cambridge, and the commute between Cambridge and Braintree was $4^{\circ}$ minutes without traffic, but well over an hour with traffic. Tonya had a very old car, and on the way to work a month after the move the transmission broke. She barely had to drive when she lived in Cambridge, so this was not a problem, but in her new life in Braintree, it was. Tonya could not afford to fix her car or get a new one, particularly after she had to pay to move her furniture and other goods to her mother's house. Further, since Tonya did not pursue action against her landlord when he did not return her security deposit, that money was unavailable.

Tonya's only option was to take public transportation to work each day and also to drop her children off at daycare. The whole process took over two hours each way (with buses, bus transfers, and the subway), and the buses and trains were often late. After two months of several tardies, her employer in Cambridge told her it was no longer working out. Since she was fired, rather than laid off, she did not qualify for unemployment benefits. Instead, she went on welfare and applied for an increase in food stamps. She searched for a job non-stop, but was unable to find one. She thinks she got close a few times, but then the employer called her former employer and found out that she "had a punctuality problem." Tonya stayed on welfare and increased food stamps for over a year before finally finding another job, closer to her mother's house in Braintree. Eventually, she ended up back in Cambridge, in public housing, and once again had to find a new job.

The counterfactual of what might have happened if Tonya had sought the help of a lawyer when her landlord first threatened to evict her is impossible to know. A good guess would be that she would have had, at a minimum, more time to pursue living options closer to her job before having to leave her apartment, and perhaps she never would have lost her job. In that case, she would not have needed over a year of welfare benefits as well as increased food stamp benefits. Indeed, perhaps she would not have had to move at all, or perhaps she would have received her security deposit back, which would have allowed her to buy a new car. We cannot know, but what we do know is that by not pursuing help from a lawyer, Tonya had no chance of staying in her apartment, and her move triggered an expensive (and perhaps 
psychologically costly) cascade of negative events in her life. Understanding why Tonya was unwilling to seek legal help can help us to design policy that considers cognitive/cultural barriers to access when deciding how limited resources should be allocated in the legal services domain. 


\section{APPENDIX: CIVIL JUSTICE SURVEY}

Has anyone in your household in the past five years experienced any of the following? 166

\begin{tabular}{|c|c|c|}
\hline 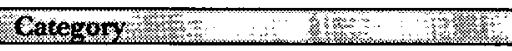 & YES & NO \\
\hline \multicolumn{3}{|l|}{ Personal Finances/Consumer } \\
\hline \multicolumn{3}{|l|}{ Problems with Creditors } \\
\hline \multirow{2}{*}{\multicolumn{3}{|c|}{$\begin{array}{l}\text { Problems Related to Insurance } \\
\text { Problems Obtaining Credit }\end{array}$}} \\
\hline & & \\
\hline \multicolumn{3}{|l|}{ Tax Problems } \\
\hline \multicolumn{3}{|l|}{ Bankruptcy-Related Problems } \\
\hline \multicolumn{3}{|l|}{ Problems Related to Contracts } \\
\hline \multicolumn{3}{|l|}{ Consumer Fraud/Defective Products } \\
\hline \multicolumn{3}{|l|}{ Problems Collecting on a Debt } \\
\hline \multicolumn{3}{|l|}{ Housing/Real Property } \\
\hline \multicolumn{3}{|l|}{ Unsafe Rental Housing } \\
\hline \multirow{2}{*}{\multicolumn{3}{|c|}{$\begin{array}{l}\text { Problems with a Landlord } \\
\text { Problems with Utilities }\end{array}$}} \\
\hline & & \\
\hline \multicolumn{3}{|l|}{$\begin{array}{l}\text { Problems with Utilities } \\
\text { Housing Discrimination }\end{array}$} \\
\hline \multicolumn{3}{|l|}{ Real Estate Ownership Problems } \\
\hline \multirow{2}{*}{\multicolumn{3}{|c|}{$\begin{array}{l}\text { Problems with Tenants } \\
\text { Property Riahts Iscues }\end{array}$}} \\
\hline \multirow{2}{*}{\multicolumn{3}{|c|}{$\begin{array}{l}\text { Property Rights Issues } \\
\text { Real Estate Transaction }\end{array}$}} \\
\hline & & \\
\hline \multicolumn{3}{|l|}{ Mobile Home/Park Problems } \\
\hline \multicolumn{3}{|l|}{ Community and Regional } \\
\hline \multicolumn{3}{|l|}{ Inadequate Policing } \\
\hline \multicolumn{3}{|l|}{ Inadequate Municipal Services } \\
\hline \multicolumn{3}{|l|}{ Environmental Health Hazards } \\
\hline \multicolumn{3}{|l|}{ Opposition to Proposed Facility } \\
\hline \multicolumn{3}{|l|}{ Family/Domestic } \\
\hline \multicolumn{3}{|l|}{ Household/Marital Dissolution } \\
\hline \multirow{2}{*}{\multicolumn{3}{|c|}{$\begin{array}{l}\text { Problems with Child Support } \\
\text { Domestic Violence }\end{array}$}} \\
\hline & & \\
\hline \multicolumn{3}{|l|}{$\begin{array}{l}\text { Domestic Violence } \\
\text { Prenuptial Agreements }\end{array}$} \\
\hline \multicolumn{3}{|l|}{$\begin{array}{l}\text { Prenuptial Agreements } \\
\text { Elder Exploitation/Abuse }\end{array}$} \\
\hline \multicolumn{3}{|l|}{ State Intervention in Family } \\
\hline Employment Related & & \\
\hline Discrimination in Hiring & & \\
\hline Problems with Compensation & & \\
\hline Discrimination on the Job & & \\
\hline Problems with Working Conditions & & \\
\hline Workers' Comp \& Unemployment & & \\
\hline Job-Related Threats to Privacy & & \\
\hline Problems with Pension Plans & & \\
\hline Problems with Fringe Benefits & & \\
\hline Problems of Self-Employed & & \\
\hline
\end{tabular}

166. The categories of this survey are modeled after CONSORTIUM ON LEGAL SERVS. \& THE PUB., supra note 3, app. B. 


\begin{tabular}{|c|c|c|}
\hline Personal/Economic Injury & & \\
\hline Suffered Injury & & \\
\hline Victim of Slander or Libel & & \\
\hline Charged with Causing Injury & & \\
\hline Health/Health Care-Related & & \\
\hline Problems with Charges or Payments & & \\
\hline Barriers to Health Care & & \\
\hline Violations of Patients Rights & & \\
\hline Environmental Health Problems & & \\
\hline Wills/Estates/Advance Directives & & \\
\hline Wills/Estate Planning & & \\
\hline $\begin{array}{l}\text { Advance Directives (What You Want } \\
\text { Done if Something Happens to You and } \\
\text { You Are in a Coma) }\end{array}$ & & \\
\hline Estate Administration/Inheritance & & \\
\hline Public Benefits Problems & & \\
\hline Small Business & & \\
\hline Need for Advice & & \\
\hline Other Problems & & \\
\hline Children's Schooling & & \\
\hline Inappropriate Discipline & & \\
\hline Problems with Enrollment & & \\
\hline Poor Quality Education & & \\
\hline $\begin{array}{l}\text { Problems Getting Disability Resources } \\
\text { for Child }\end{array}$ & & \\
\hline Other Civil Rights/Liberties & & \\
\hline Improper Search or Seizure & & \\
\hline Free Speech/Religion Violation & & \\
\hline Voting Rights Violation & & \\
\hline Interference with Other Rights & & \\
\hline Discrimination Related to Disabilities & & \\
\hline $\begin{array}{l}\text { Legal Needs of Immigrants and } \\
\text { Speakers of Other Languages }\end{array}$ & & \\
\hline Language-Related Problems & & \\
\hline Immigration-Related Problems & & \\
\hline Exploitation and Other Problems & & \\
\hline Military Personnel/Veterans Needs & & \\
\hline Military Service Related Problems & & \\
\hline Needs of Veterans & & \\
\hline Vocational Training-Related Issues & & \\
\hline
\end{tabular}




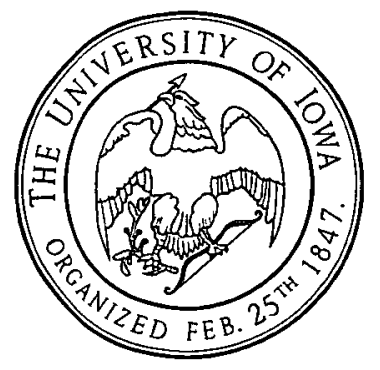

